\title{
NATO Enlargement to Ukraine and Georgia: Old Wine in New Bottles?
}

\section{Dušica Lazarević *}

\begin{abstract}
This article examines the question of possible NATO enlargement to Ukraine and Georgia, although it will not venture to provide a firm answer as to its likelihood. The aim of the essay is to offer an accurate analysis of the aspiration of these two former Soviet republics to join the Alliance, with a primary focus on relations between the West (in this case, NATO) and Russia, the successor of the Soviet legacy. In the process, it will try to uncover the underlying principle of NATO enlargement as such. To this end, the article will use geopolitics as a theoretical background to explain the behavior of the parties involved, carefully taking into consideration the specific position of NATO as an alliance. Furthermore, it will elaborate the debates over each post-Cold War round of enlargement, with special focus on the first post-Cold War round of NATO enlargement, as this event established the fact of Alliance expansion and laid out the rules for future enlargement rounds. Studying the positions of Ukraine and Georgia in the context of cooperation with NATO, the article addresses the differences and similarities of the two countries, and examines separately their relations with NATO, Russia, and the United States. The overall conclusion is that the prospects for Ukraine and Georgia to accede to NATO membership are not bright, but at the same time they are not completely without prospects. Their ultimate outcome will depend on the terms - whether explicit or tacitof the ongoing transatlantic bargain between the U.S. and Russia.
\end{abstract}

\section{Introduction}

One of the most divisive issues currently facing the North Atlantic Treaty Organization (NATO) at present is the prospect of its enlargement to include Ukraine and Georgia as members. The potential accession of these two former republics of the Soviet Union to membership in NATO has been frequently discussed since the so-called "color revolutions" in Georgia in 2003 and in Ukraine in 2004. The issue was further highlighted by the crisis between Georgia and Russia in August 2008, and the gas crisis between Ukraine and Russia in early 2009. According to various opinions, those crises were consequences of the pledge made by NATO at the Bucharest Summit in April 2008 that Ukraine and Georgia would eventually become NATO member states. This statement represented the first time that the Alliance made a prediction about any nations' future membership status, and did so in a way that is inconsistent with the known practices of NATO enlargement.

Each of the three rounds of NATO enlargement since the end of the Cold War (1999, 2004, and 2009) raised similar questions and dilemmas with regard to the role, purpose, and future of the transatlantic organization. And each round was followed by increasingly voluble complaints from Russia that NATO's expansion poses a threat to

Dušica Lazarević received a master's degree from the European Institute of the University of Geneva in the field of International and European Security. This essay represents a part of the research she completed for her master thesis. 
Russia's national security. However, NATO's "open door" policy has continued to be attractive for potential new member states. At the NATO Summit in Strasbourg and Kehl in April 2009, devoted to the sixtieth anniversary of the Alliance, Croatia and Albania gained member status, increasing the size of the community to twenty-eight member states. Macedonia will be welcomed as a member when the dispute over its constitutional name is resolved with neighboring Greece. With respect to Montenegro, Bosnia and Herzegovina, and Serbia, each state has already engaged with the Alliance to some extent. It seems that the Euro-Atlantic orientation of the Western Balkans more or less depends on the will and capability of the countries of the region to meet the accession requirements. As for the remaining European countries that are not NATO members, their reasons for not seeking membership are different. Some of them-like Austria, Switzerland, or Sweden-consider themselves as traditionally neutral or militarily non-aligned. The reasons for other states' decisions not to pursue NATO membership (such as Moldova, Belarus, and Armenia) are usually derived from their recent past, including NATO's understandable reluctance in some cases to begin membership discussions. Nevertheless, each of these countries is currently engaged in NATO's Partnership for Peace program (PfP).

Georgia and Ukraine have both at certain junctures expressed their intention to join NATO, and these overtures were welcomed by NATO, as mentioned above. However, the current prospects of NATO enlargement to Ukraine and Georgia seem less than certain. The main concerns were and still are the territorial integrity of Georgia, the lack of public support for accession in Ukraine, Russia's opposition to both nations' joining NATO, and the slow progress in security sector reform in both Ukraine and Georgia.

This article will address the following questions:

1. Is the current debate about NATO enlargement to Ukraine and Georgia similar to earlier enlargement debates?

2. Does geopolitics still matter in the eastward expansion of the Alliance?

3. Why are Ukraine and Georgia part of the same "NATO enlargement package"? In other words, what are the similarities and differences between the efforts of Ukraine and Georgia in the process of integration to NATO?

4. Does the debate over NATO enlargement to Ukraine and Georgia serve as a turning point in the future engagement of Russia and the West, and thereby in Russia-NATO relations?

Although the essay recognizes the fact that every round of NATO enlargement includes political as well as military aspects, due to the complexity and breadth of the topic this article will focus on the political dimensions of the process. Given the drastic change that occurred in the geopolitical environment in the early 1990s, the first three waves of NATO enlargement during the Cold War era (Turkey and Greece in 1952, West Germany in 1955, and Spain in 1982) will not be addressed here, as is the case with German reunification in 1990. The essay will primarily focus on political concerns about NATO enlargement with respect to Russia; thus, it will not address the po- 
sition of other regional powers (such as Turkey and Iran) or other international actors (such as the European Union or the Shanghai Cooperation Organization, or SCO). Likewise, it will also leave unexamined the ongoing debates over the possible NATO accession of other European countries mentioned above, Mediterranean countries (particularly Israel), and that of the so-called "contact countries" - significant contributors to NATO missions such as Australia, Japan, South Korea, and New Zealand. ${ }^{1}$

In order to answer these questions, the first part of the article will analyze the theoretical background of Alliance expansion, seeking to find explanations for the motives of the parties involved in the enlargement process. The second section will review the debates related to NATO enlargement, and will analyze the driving forces behind the first three post-Cold War enlargement rounds in 1999, 2004, and 2009. The third section will study the historical background of the current situation involving Georgia and Ukraine, and will outline the positions of the main players involved in the process, such as Russia, the United States, and some other NATO member states. This section will analyze the similarities and differences between the Georgian and Ukrainian efforts to gain membership in NATO. The final section will include research findings and offer some answers to the questions raised above.

\section{Does Geopolitics Still Matter?}

Since its initiation at the end of the Second World War, NATO has become one of the most successful military alliances in the history of such formalized arrangements between states. As a regional organization subordinated to the United Nations (UN), NATO was created to protect its member states from the threat posed by the Soviet Union. The principle of collective defense is defined in Article 5 of the Washington Treaty (1949), NATO's founding agreement. ${ }^{2}$ The general rationale of the Alliance was famously defined by its first secretary-general, Lord Ismay: "The raison d'etre of NATO is to keep the Russians out, the Americans in, and the Germans down."3

History shows that the disappearance of reasons for the foundation of an alliance usually means the dissolution of that alliance. NATO is an extraordinary example in this regard. Instead of dissolving itself after the dissolution of the Warsaw Pact, NATO

1 For more on the NATO Concept of Global Partnership, see the NATO website at www.nato.int/docu/update/2006/04-april/e0427c.htm.

2 Article 5 reads as follows: "The Parties agree that an armed attack against one or more of them in Europe or North America shall be considered an attack against them all and consequently they agree that, if such an armed attack occurs, each of them, in exercise of the right of individual or collective self-defense recognized by Article 51 of the Charter of the United Nations, will assist the Party or Parties so attacked by taking forthwith, individually and in concert with the other Parties, such action as it deems necessary, including the use of armed force, to restore and maintain the security of the North Atlantic area." The North Atlantic Treaty, ratified in Washington D.C. on 4 April 1949; full text available at www.nato.int/ cps/en/natolive/official_texts_17120.htm.

3 Peter W. Rodman, "Will NATTO Survive?" National Review (31 July 1995); available at http://findarticles.com/p/articles/mi_m1282/is_n14_v47/ai_17367752/. 
has managed to adjust itself to the new security environment, and has enlarged its membership to almost twice its size at the end of the Cold War. (The reasons for NATO's continued existence will be addressed in the next section of this article.) It is important to stress here that, aside from the broader security agenda, NATO is still an alliance for collective defense, not for collective security.

The focus of this essay is NATO enlargement based on the Article 10 of the Washington Treaty, ${ }^{4}$ particularly with respect to relations between NATO and the successor of its former adversary, Russia, regarding the eastward enlargement of the Alliance. One may notice a growing discrepancy in the terminology the two sides use when discussing the enlargement issue. While NATO and its member states use rhetoric highly inflected by theories of liberalism, such as "open door policy," "spreading democracy," "rule of law," "shared values," and "common interest," the Russians typically use language that has its roots in the realm of geopolitics, such as "privileged interests," "near abroad," and "red line." That discrepancy became more pronounced in the debates on Ukraine and Georgia's potential membership, given that Russia sees these former Soviet republics as being within its "sphere of interest." Furthermore, Russian officials claim that, although NATO's actions may be cloaked in liberal rhetoric, they are actually motivated by geopolitical considerations. ${ }^{6}$ In order to understand the nature and development of trends within NATO as an alliance, it is important to first examine the theoretical background of alliance dynamics, and to consider NATO expansion from a geopolitical perspective.

\section{NATO as an Alliance}

In Stephen Walt's definition, "an alliance is a formal or informal commitment for security cooperation between two or more states." "7 The agreement may be based on a written treaty or oral commitment between interested parties. According to Walt, "the primary purpose of most alliances is to combine the members' capabilities in a way that furthers their respective interests." ${ }^{\circ}$ Walt distinguishes between offensive and defensive alliances, and stresses that an alliance is not the same as a collective security ar-

4 Article 10 of the North Atlantic Treaty reads as follows: "The Parties may, by unanimous agreement, invite any other European State in a position to further the principles of this Treaty and to contribute to the security of the North Atlantic area to accede to this Treaty."

5 In testimony before the U.S. Senate Committee on Foreign Relations in 2008, former U.S. Assistant Secretary for European and Eurasian Affairs Daniel Fried testified: "NATO is not just a military alliance; it is an alliance of values." Daniel Fried, "NATO: Enlargement and Effectiveness," Brookings.edu (11 March 2008); available at www.brookings.edu/testimony/ 2008/0311_nato_gordon.aspx.

6 Russian Foreign Minister Sergei Lavrov rhetorically asked, "How can democracy be promoted by a military-political alliance that, within the framework of its transformation, has been consistently increasing the number of scenarios for the possible use of force?" Sergei Lavrov, "Containing Russia: Back to the Future?" Russia in Global Affairs (October-December 2007); available at http://eng.globalaffairs.ru/numbers/21/1147.html.

7 Stephen M. Walt, “Why Alliances Endure or Collapse," Survival 39:1 (Spring 1997): 157.

8 Ibid. 
rangement. Rather, alliances are exclusive bodies, and are generally temporary rather than permanent compositions.

On the question of why alliances are formed, Walt sees the answer in the collective provision of security. Nations create alliances primarily as a response to perceived threats to their individual member nations' security. The source of the threat could be external or domestic, and it defines two different approaches in the creation of alliances. The former, "focused on external security, is linked to realism that has tended to draw on relations among great powers; the latter, focused on internal security, scruti-

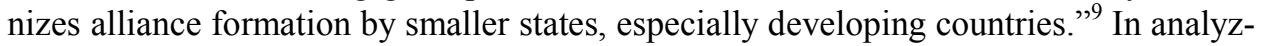
ing the reasons why alliances endure or collapse, Walt elaborated: "Alliances are more likely to persist when there is a large asymmetry of power within them, when the allies share similar political values, and when the relationship is highly institutionalized. Such alliances will find it easier to adapt to new conditions and will be better equipped to handle the conflicts of interest that inevitably arise." 10

NATO partly fits into this model. Having the U.S. as a driving force able to maintain the allies' unity, this alliance is highly institutionalized and composed of likeminded countries based on the principles of representative democracy, rule of law, and market economics. Regarding the question of time and the typically temporary nature of alliances, NATO found a way to adapt itself to the new environment of the postCold War era by addressing a new range of issues and by elevating the political dimension of the Alliance to equal importance with the military aspect. ${ }^{11}$ Enlargement has become one of the most vital instruments for NATO to fulfill its new tasks. Despite the vast changes in the geostrategic environment in the past twenty years, however, NATO's core mission has remained unchanged: NATO was created for the purpose of the collective assurance of the national security of the member states, based on the principle of collective defense.

\section{Explanation of Geopolitics}

The field of geopolitics encompasses the analysis of the interaction between geographic, social, and political aspects in the development of states, and how these fac-

9 Ibid.

${ }^{10}$ Ibid., 170.

11 "Classical alliances were forged to deal with a specific threat, and once that threat had been overcome or defeated, they dissolved again. NATO is different. First, it is a permanent alliance. Second, NATO was never just a military alliance to deal with a singular threat. NATO gave a politically, economically and morally devastated Europe the necessary reassurance to cope with the many challenges that it faced. And it created the security framework that allowed former wartime enemies to become friends, and to get on with the new project of European integration. Finally, and perhaps even more important, is the difference between NATO and traditional military alliances: NATO is framework for political change-indeed, it is an instrument to shape change." NATO Secretary-General Jaap de Hoop Scheffer, speech at an event jointly organized by the Institute for National Security Studies and the Atlantic Forum of Israel, Tel Aviv, 11 January 2009; available at www.nato.int/cps/en/ natolive/opinions_49673.htm. 
tors influence their relations with other states. The Swedish political scientist who coined the term in 1899, Rudolph Kjellen, defined geopolitics as "the theory of the state as a geographical organism or phenomenon in space."12 The American political scientist Edmund Walsh saw geopolitics as being based upon international justice, "as a combined study of human geography and applied political science...dating back to Aristotle, Montesquieu, and Kant."13 Geoffrey Sloan defined it as the "theory of spatial relationship and historical causation whose perspective is the international system as a whole." 14

John Hillen and Michael Noonan made a distinction between two broad schools of geopolitics, one focused on organic state theory and the other on geostrategy. Organic state theory is represented by Fridrich Ratzel (1844-1904) and the previously mentioned Rudolph Kjellen (1864-1922). This school argues that states are like living organisms, and that the size of the state and the amount of natural resources it possesses define its strength. The geostrategic school is represented by Alfred Mahan (18401914), Sir Halford Mackinder (1861-1947) and Nicholas J. Spykman (1893-1943). Mahan argued that sea power is a state's most important strategic consideration. Mackinder countered Mahan with an argument that "inventions such as the railroad would cause land power to be the determinant in international affairs." ${ }^{15}$ For Mackinder, the area of key strategic importance in the world was what he termed the "Heartland," by which he meant the core of Eurasia (or "World-Island"), composed of Western Russia, Ukraine, and Mitteleuropa. ${ }^{16}$ Mackinder wrote: "Who rules the Heartland commands the Heartland. Who rules the Heartland commands the World-Island. Who rules the World-Island commands the world." Mackinder projected that Eastern Europe would be the crucial element of terrain for balancing the Heartland's power. His theories seemed to presage the origin of the Cold War and Western perceptions of the Soviet threat. Spykman offered a different solution. According to him, it was not the Heartland that was of crucial strategic importance, but rather "Rimland," the areas that border directly on Heartland. For states in Rimland, sea power is very important, because "who controls the Rimland rules Eurasia; who rules Eurasia controls the destinies of the world."18

12 Saul B. Cohen, Geopolitics of the World System (Lanham, MD: Rowman \& Littlefield, 2002), 11 .

13 Ibid.

14 John Hillen and Michael P. Noonan, "The Geopolitics of NATO Enlargement," Parameters 28:3 (Autumn 1998): 24.

15 Ibid., 25.

16 Mitteleuropa is composed of: Austria, Croatia, the Czech Republic, Germany, Hungary, Liechtenstein, Poland, Slovakia, Slovenia, Switzerland, Lithuania, Latvia, and Estonia (along with parts of Romania and Serbia).

17 Halford Mackinder, Democratic Ideals and Reality (New York: Henry Holt and Co., 1919), 106.

18 Nicholas J. Spykman, The Geography of the Peace (New York: Harcourt, Brace, and Co., 1944), 43. 
Geopolitics as a science was disrespected by geopolitik, the German version of geopolitics, which was deeply rooted in the ideologies of the National Socialists. The revival of geopolitics took place during the 1980s, and since then it has represented a significant element of the description of contemporary phenomena in international relations.

\section{Geopolitics and the Alliance}

Although the Alliance does not use geopolitical rhetoric in its official communications, in the opinion of some observers, NATO's actions are motivated by geopolitical considerations. Hillen and Noonan noticed that NATO officials have stated on the record that "enlargement will do nothing to dilute NATO's focus, that following enlargement the Alliance's core mission will remain the collective defense of NATO soil, and the addition of new members will improve its ability to carry out this mission.",19

Given this stated view on the part of some NATO officials, Hillen and Noonan attempted to uncover the reasons why geopolitical considerations - which are clearly still relevant for the Alliance - were never mentioned during the debates over the first round of enlargement. In order to explain "the gap between rhetoric and the reality," they offered three possibilities:

- The politicians who were negotiating the expansion might not understand what a military alliance is and what it does

- Geopolitical considerations were purposefully excluded from the first round of enlargement discussions in order to make the process smoother; in further enlargements, geopolitics will be more important, especially considering the question of selecting future candidates for accession to the Alliance

- If NATO should become a global (rather than a regional) actor for collective security (which is the opinion of some within the Alliance), then geopolitics really will not matter.

However, the core of NATO's security arrangement has remained unchanged since its foundation in 1949. The proposal made by the Soviet Union in 1954 for the unification of the two rival military pacts into one which would be in charge of collective security for all of Europe had never been seriously considered. After the dissolution of the Warsaw Pact, NATO has not only continued to exist, but has also expanded further eastward. The possibility of Russia's inclusion in the Alliance, although never officially offered by the Russians, has never been a part of NATO's strategic consideration. Given that the stabilization and democratization of the former communist states was a primary rationale for NATO enlargement after the end of the Cold War, Michael Mandelbaum questioned the way the Alliance dealt with this issue in the first enlargement round:

To the extent, moreover, that NATO membership is relevant to assisting in the development of stable democratic politics, it was being contemplated for the wrong countries.

19 Hillen and Noonan, "The Geopolitics of NATO Enlargement," 22. 
The most appropriate candidates were not the Visegrad Four but rather Russia and Ukraine, where five years after the collapse of the Soviet Union democracy was shakier and the stakes for the West were higher because of the importance of the countries themselves. $^{20}$

Indeed, Ukraine has been seen as a potential NATO member since the lifting of the Iron Curtain, but Russia has not.

Since the fall of the Berlin Wall, the Alliance's approach to the new security environment has been rooted a strong sentiment of the indivisibility of security. NATO is a specific alliance that manages to strengthen the national security of its member states by strengthening the security of its overall environment. The terrorist attacks of 11 September 2001, which prompted NATO to activate the Article 5 provisions for the first time in its history, simply confirmed the importance of displaying a common response to global threats. NATO uses a particular discourse to explain its intentions and behavior, but this discourse fails to explain why the democratization of the NATO environment does not extend to Russia, the country whose security is strongly linked to that of Europe.

From the other side of the divide, Russia sees NATO as an extension of the power of the United States. As such, although NATO enlargement is viewed in a very negative light in Russia, being seen as a process targeted directly against Russia's national security, it is obvious that not every candidate for NATO membership poses the same level of concern in Moscow. Russia opposed NATO enlargement to the Baltic States, but it was too weak to prevent it at the time. Although it did not raise many complaints about the expansion of NATO membership to the states in the Western Balkans, Russia nowadays feels much more empowered to protect what it considers as its near abroad, and to draw a "red line" in the path of enlargement path in the case of Ukraine and Georgia. What Russia has failed to explain is that it is not sufficient to portray all aspects of an issue as complex enlargement in terms of geopolitics. How, for instance, can one county be prevented from joining an international organization if it is the free will of its citizens? If this is not the case with Ukraine, it certainly describes the situation of Georgia.

Geopolitics still matter. From the period of the creation of NATO until the present, geopolitics has been a continually important consideration in the formation and expansion of the Alliance. If we apply Mackinder's Heartland theory to the NATO enlargement process, the strategically important territories in Eastern Europe are not (yet) under NATO's umbrella. Coincidentally or not, that is currently the major matter of dispute between Russia and the West. Nevertheless, given that geopolitical theory is a product of a specific historical moment, one should keep in mind that the global environment has changed dramatically since the end of World War II, and Russia and the U.S. are no longer the main global rivals.

20 Michael Mandelbaum, The Dawn of Peace in Europe (New York: The Twentieth Century Fund Press, 1996), 51. 
Even if we assume that the enlargement process is being driven by geopolitical reasons as such, it still does not necessarily imply that there must be confrontation between NATO and Russia. As has been stressed many times by both sides, cooperation would be mutually beneficial. Many issues are on the agenda for discussion between Russia and NATO, but the most important are the situation in Afghanistan and the prevention of proliferation of weapons of mass destruction. In light of these issues, it could be that the question of further NATO enlargement becomes a factor in a wider transatlantic bargain. Nevertheless, there are limits to cooperation between Russia and the West, and it could be that the continuation of NATO expansion tests these limits. According to Vladimir Baranovsky and Alexei Arbatov, "Russia's foreign and security policy has a specific focus upon certain sub-regions: the Baltic Sea area; the Black Sea area and the Transcaucasus. Whatever broader considerations Russia might have with respect to Euro-Atlantic developments in general, Russia's sensitivity towards those areas will probably remain." ${ }^{21}$

\section{The Debates on NATO Enlargement}

Almost two decades since the dissolution both of the Soviet Union and the Warsaw Pact, NATO has enlarged three times, adding twelve new member states from Central and Southeastern Europe. One might think that NATO enlargement has been a wellplanned process, based on an agenda prepared long in advance. For the purposes of the article, however, it is more important to consider what one thinks about the continuation of the enlargement process on the basis of the same agenda, despite changes in the security environment. To put it in the Clinton Administration's wording, the question of NATO enlargement is "not whether but when." This section will try to challenge the seeming inevitability behind that formulation. Due to the fact that at the end of the Cold War the main question for NATO was not its expansion but its further existence, and given the relevance of this issue for the rest of this essay, this section will first briefly elaborate the prevailing reasons for the survival of NATO.

\section{NATO's Survival}

In the early 1990s, opinion about the future of NATO was divided. Views oscillated between calls for NATO's dissolution to visions of NATO expanding beyond the Euro-Atlantic region to become a global player. The reasons why and how NATO survived may be grouped roughly into three categories:

- Absence of an alternative for NATO. With the new post-Cold War reality in Europe, many saw the Conference on Security and Cooperation in Europe (CSCE) as a new mechanism that would replace NATO (after 1994, it became known as the Organization for Security and Cooperation in Europe, or OSCE). This organization already included all the members of NATO and the

${ }^{21}$ Vladimir Baranovsky and Alexei Arbatov, "The Changing Security Perspective in Europe," in Russia and the West: The 21st Century Security Environment, eds. Alexei G. Arbatov, Karl Kaiser, and Robert Legvold (New York: East West Institute, 1999), 59. 
former Warsaw Pact, and was seen as offering the possibility of providing a solid basis for a new, fresh transatlantic dialogue. But enthusiasm about OSCE waned after the first Gulf War, which was quickly followed by the crisis in the former Yugoslavia. The EU experienced similar humiliation of being incapable of responding efficiently to a crisis in its own backyard. It was this overwhelming sense that no other institutions were competent to act that "convinced NATO members that the Alliance remained the most viable institution to assure European security.",22

- U.S. presence in Europe. Gale Mattox and Arthur Rachwald write that, "For the [first] Bush administration, it was through NATO that the U.S. maintained its strong institutional ties to Europe." 23 According to this view, the dissolution of NATO was out of question for President George H.W. Bush primarily because of Europe, not because of Russia.

- NATO's bureaucratic self-interest: Richard Betts writes, "Institutions take on lives of their own; they have a self-preservation instinct, and successful ones especially want to keep validating their importance." 24 This reason is not of equal importance to those mentioned above, but it had a definite (although limited) influence in shaping the Alliance's destiny.

Once it had survived the crisis moment of collapse of Soviet power, NATO started to look for new challenges. The idea of enlargement very soon became one of the Alliance's priorities.

\section{9: Historical Watershed or Expected Scenario?}

The evidence that NATO did not have a premeditated eastward enlargement policy is clear from the statement of NATO's then secretary-general, Manfred Worner, in 1989: "NATO did not want a shift of balance or an extension of its military borders to the east." ${ }^{25}$ The same applied for the United States. ${ }^{26}$ The initiative for NATO enlargement was officially mentioned for the first time at the NATO Summit in Brussels in 1994, followed by the Study on NATO Enlargement in the next year. For the Clinton Administration, which won two national elections in the U.S. on platforms of domestic poli-

22 Gale A. Mattox and Arthur R. Rachwald, "Introduction: European Security and the Enlargement of NATO," in Enlarging NATO: The National Debates, eds. Gale A. Mattox and Arthur R. Rachwald (Boulder, CO: Lynne Rienner Publishers, 2001), 6.

23 Gale A. Mattox, “Accepting New Allies?” in Enlarging NATO, eds. Mattox and Rachwald, 17.

24 Richard K. Betts, "The Three Faces of NATO," The National Interest Online (3 February 2009); available at www.nationalinterest.org/Article.aspx?id=20944.

25 Gerald B.H. Solomon, The NATO Enlargement Debate, 1990-1997: Blessings of Liberty (Washington, D.C.: Center for Strategic and International Studies, 1997), 7.

26 "The U.S. decision to extend NATO membership to countries formerly belonging to the Warsaw Pact was highly controversial, and it was by no means inevitable." For more detail, see James M. Goldgeier, Not Whether but When (Washington, D.C., Brookings Institution Press, 1999), 4. 
tics, it was not a priority issue in the first year of its mandate. Although, as Stanley Sloan formulated, "the Bush Administration had put the process on the track,", it was Clinton personally who gave an impetus to NATO expansion and made this policy manageable.

According to James Goldgeier, the reasons for this policy shift were twofold: the superior U.S. position in the world and the capability of the proponents of enlargement within the Clinton Administration to best their opponents' arguments. Goldgeier writes:

First, the United States was so powerful vis-à-vis both the Europeans and the Russians that once it decided to follow through, there was little that could be done to prevent enlargement from happening. ... Second, within the United States no large organized domestic political constituency opposed expansion; while enlargement never became a big issue for the public, enlargement supporters were able to outorganize the community (largely academics and columnists) that opposed the policy. ${ }^{28}$

Furthermore, the circumstances were in favor of enlargement, given "the general concern about instability in central and eastern Europe," and the necessity for the Clinton administration to "show that America could continue to lead in the post-cold war world." 29

The "Russian factor" in shaping NATO enlargement policy was significant in many respects. First, it was Russia that was the successor of the Soviet Union, the driving force behind the Warsaw Treaty. According to many observers at the time, the future of NATO was the most important indicator of the future of relations between Russia and the West. Second, there were strong indications that, during the process of Germany's reunification and its smooth integration into NATO in 1990, the U.S. made clear promises to Russia that NATO was not going to be enlarged to the east. ${ }^{30}$ Many argued that cooperation with Russia in the field of control of nuclear weapons and other vital topics should have priority over giving security guarantees to the former communist states of Central Europe. According to them, NATO's eastward expansion could make Russia suspicious, and might jeopardize its democratization process. One could conclude that those opinions were seriously considered given the fact that the U.S. administration put the subject of enlargement on hold during the legislative and presidential elections in Russia in 1995 and 1996.

Russia experienced a period of great difficulty during the 1990s. Moscow lost its superpower status, and indeed was reduced to being seen as simply a regional power. As a country in transition, Russia was overwhelmed with economic and social problems. Russian policymakers had bigger problems to address at that time than NATO

27 Stanley R. Sloan, NATO, the EU, and the Atlantic Community: The Transatlantic Bargain Reconsidered (Lanham, MD: Rowan \& Littlefield, 2003), 137.

28

29

Goldgeier, Not Whether but When, 4.

Ibid., 9.

30 According to this opinion, a promise of non-extension of NATO was given as an answer to Russia's concerns over a Germany that would be enrolled in two alliances at once; see ibid., 15. 
enlargement. But, as Irina Kobrinskaya explains, "despite the chaotic nature of Russian foreign policy, attitudes in decision-making circles concerning NATO enlargement remain relatively constant and negative." ${ }^{\prime 31}$ Furthermore, she elaborates that the debates on NATO enlargement started in Russia as early as 1993, and were an important factor in the creation of Russian domestic and foreign policy. Nevertheless, internal debates are very often shaped by the political establishment, and the assessment of Russia's political elite at the time was that the country had no alternative but to forge closer connections with the West. The consequence was the Founding Act on Mutual Relations, Cooperation, and Security between NATO and the Russian Federation, which was signed in May 1997 in Paris. Certainly, Kobrinskaya reflected that the first wave of NATO enlargement was not seen as a military threat, and did not cause "changes in the Russian security doctrine or the structure or allocation of its forces, budgetary decisions or force levels.",32

The question "Who is going to be invited?" was announced by the U.S. Secretary of Defense William Cohen in June 1997, before consultations with the Allies about NATO expansion had been concluded. ${ }^{33}$ The U.S. view was that Hungary, Poland, and the Czech Republic had made the most progress in reforming their militaries, ensuring civilian control, and developing democratic institutions and a free market. Slovakia, originally part of the "Visegrad Four," was left out because of its internal political turmoil. Slovenia and Romania were considered for potential candidacy as well, with backing from Italy and France, but at that time they were not regarded as serious candidates for membership.

Member states had various concerns and observations about the enlargement process. One group of countries supported the process because the Clinton Administration was advocating it, while the less enthusiastic group was motivated primarily by its own security considerations (for Italy and Greece, the stabilization of the Balkans played a major role). Germany was the strongest European advocate for the first wave of NATO enlargement. Actually, then German Defense Minister Volker Rühe was the first to call for the accession of the new member states in 1993. German interest in the eastward expansion of the Alliance was largely driven by a desire to extend the line of stability to those counties that bordered Germany to the east. Germany was concerned about whether Russia would see enlargement as a threat, and strongly supported deepening relations between that country and the Alliance. In that respect, the signing of the Founding Act between NATO and Russia was seen as a well-balanced policy.

The U.K. was another strong NATO advocate and a loyal ally of the United States. Regarding NATO enlargement, the British government saw it as a positive process that should be managed carefully to prevent weakening the Alliance and/or increasing tensions in the rest of the continent. Prime Minister Tony Blair supported a "smaller

31 Irina Kobrinskaya, "Russia: Facing the Facts," in Enlarging NATO, eds. Mattox and Rachwald, 184.

32 Ibid., 180.

33 For more details, see Sloan, NATO, the EU, and the Atlantic Community, 148-49. 
rather than a larger" expansion of the Alliance, and favored the accession of Hungary, Poland, and the Czech Republic. ${ }^{34}$

France called for a renovation of NATO before any enlargement occurred. The main French argument was that NATO should first clarify a new mission for itself before inviting new members. France advocated for the strengthening of European security policy. Although France failed to find allies to support its position, it endorsed the Alliance expansion in $1996 .^{35}$

Italy suffered from a strong case of "fear of exclusion syndrome," and tried to avoid being excluded from the club of the European countries that were considered to be "significant powers" (France, Germany, and the U.K.). Yet, as Roberto Menotti writes, "Even those opposed to or undecided about enlargement soon realized that Italy was in no position to forestall the process once it was set in motion by a determined U.S. government." 36

The real costs of enlargement remain unclear. Although there have been three studies on enlargement costs - conducted by the Clinton Administration, the Congressional Budget Office (CBO), and RAND Corporation in 1996 and 1997-the estimates were very different. NATO conducted its internal cost study in 1997, but did not publish its findings. According to a report by the Congressional Research Service, the Clinton Administration estimated the cost of adding "a small group" of countries at USD 27-35 billion between 1997 and 2009. RAND cost estimates ranged from USD 10 to 110 billion, while the CBO estimated the costs as being anywhere from USD 21 billion to 125 billion. ${ }^{37}$ The reasons for such variation between the three reports are in the different range of threat assumptions that the estimates were based on, and due to the presumed different levels of interoperability deemed necessary to qualify aspirant states for accession. Additionally, the Clinton Administration and RAND were strongly in favor of enlargement, and were thus eager to downsize the assessment of the potential costs, whereas $\mathrm{CBO}$ was neutral.

Hungary, Poland, and the Czech Republic became NATO member states in March 1999. It rapidly became apparent that they were not ready to meet the Alliance's standards, as a result of which NATO learned its lessons and introduced the Membership Action Plan (MAP). MAP, a practical manifestation of the "open door policy," is divided into five chapters that describe the requirements for the membership: political and economic issues, defense/military issues, resource issues, security issues, and legal issues. The overall idea of MAP was to control the process of NATO integration by setting out a program of steps to follow and standards to meet to assist aspiring countries in their preparations for possible future membership. Participation in MAP does

34 Timothy Garden, "The United Kingdom: Making Strategic Adjustments," in Enlarging NATO, eds. Mattox and Rachwald, 80.

35 For more details, see Paul Gallis, "France: NATO's "Renovation" and Enlargement," in Enlarging NATO, eds. Mattox and Rachwald, 55-75.

36 Roberto Menotti, "Italy: Uneasy Ally," in Enlarging NATO, eds. Mattox and Rachwald, 104.

37 Congressional Research Service, NATO Expansion: Cost Issue, CRS Report for Congress, Report No. 97-688 (Washington D.C.: Congressional Research Service, 2 July 1997). 
not guarantee a state membership in NATO. Rather, its objective is to inspire aspirant countries to achieve their own goals: to meet membership requirements; to be ready to contribute to NATO; and to become a partner in ensuring transatlantic security. MAP might also be used as an instrument to prolong the process of possible accession to the Alliance, if doing so were in the interests of NATO.

For the proponents of NATO enlargement, the first round was a huge success. Despite a few initial hiccups, the ice had been broken, and nothing bad happened. Although Russia was generally opposed to the process, it continued with a "business as usual" approach to the Alliance and the allies. Having established a template for enlargement, and then having enhanced it with MAP, NATO was ready to continue to work on "unfinished business" with the remaining potential member states, a process that continued undisturbed until April 2008.

\section{4: The "Big Bang” Approach}

As Stephen Larrabee asserted, NATO enlargement had not been a major issue in transatlantic relations after the Washington summit. The Clinton Administration decided to leave that issue for the administration of the next U.S. president. Stanley Sloan noticed that this relieved the European allies for two reasons. First, having accomplished its goals with the first enlargement round, Germany was not especially enthusiastic about continuing the process. Second, the European countries knew that the next round of negotiations about membership expansion would include the Baltic States, which would be strongly opposed by Russia. ${ }^{38}$

Larrabee argues that the second round of enlargement was uncertain for many reasons. Most important, it was not apparent what the strategic rationale was for this round of expansion. Unlike the first round, where the stabilization of Central Europe was generally accepted as a legitimate strategic rationale by the Allies, in the second round the Alliance had no single rationale, but a few different ones: stabilizing Southeastern Europe; completing the stabilization of Central Europe; and/or including the Baltic countries. NATO also had no clear agreement about potential candidates. In addition, unlike in the first round, there was no strong European power pushing for enlargement, since Germany's enthusiasm had waned. ${ }^{39}$

The first policy shift regarding NATO enlargement happened when U.S. President George W. Bush outlined his vision of a Europe "whole, free, and at peace" in June 2001 in Warsaw. He said that all European democracies "from the Baltic to the Black Sea and all that lie between" should be able to join European institutions, especially NATO.$^{40}$ The second major policy shift came with the events of September 11 in the same year.

38 For more details, see Sloan, NATO, the EU, and the Atlantic Community, 154-55.

39 For more details, see Stephen Larrabee, "NATO Enlargement: Prague and Beyond," paper prepared for the IISS/CEPS European Security Forum (9 July 2001); available at www.isn.ethz.ch/isn/Digital-Library/Publications/Detail/?ots591=CAB359A3-9328-19CCA1D2-8023E646B22C\&lng=en\&id=22222.

40 Cited in Sloan, NATO, the EU, and the Atlantic Community, 156. 
In Larrabee's opinion, Bush's Warsaw message to Moscow was that the U.S. would take a tougher, more "realistic" approach in its bilateral relations with Russia. Furthermore, the inclusion of one or more Baltic counties would make it clear that Washington would not accept "red line" that Russia might wish to impose regarding what it saw as its sphere of interest. It demonstrated that the West was willing to disabuse Russia of two beliefs: first, that it can veto the security orientation of any state regardless of its geographic location; and second, that the West accepts the Baltic States (or any other former Soviet republic) as part of Russia's sphere of influence.

The aftermath of September 11 made the U.S. push harder for NATO enlargement as it sought loyal allies in the war on terror. This made its European allies move toward closer solidarity with U.S. policy and less reluctant to oppose further enlargement as such. Russia, which also joined the war on terror, took a softer position on the matter. While the Duma and the bulk of public opinion was still firmly anti-NATO, given the problems that Russia had with the ongoing conflict in Chechnya, Russian President Vladimir Putin saw cooperation in the fight against terrorism as a priority over opposition to the expansion of the Alliance.

The "big bang" approach prevailed, and at the NATO Summit in Prague in November 2002, the Alliance issued invitations for membership to Latvia, Lithuania, Estonia, Slovenia, Slovakia, Bulgaria, and Romania. Croatia, Albania, and Macedonia were left out of this group, although they were given strong support to continue with further reforms. In March 2004, those seven candidates became NATO member states.

The terrorist threat made many topics irrelevant that would normally have been prominent parts of the enlargement debates such as its cost, the capability of the Alliance to assimilate new member states, the fears of divisions among allies, the capability of the prospective members to make any meaningful military contribution to NATO, etc. In addition, the first wave of enlargement did not cause any internal division within NATO, which made the allies confident that enlargement would not endanger the cohesion of the Alliance. Larrabee concluded that NATO's decision to bring in seven candidates at once prevented the Alliance from having "to fight the same battle over again every few years." ${ }^{41}$ Such a large round of enlargement raised a lot of questions. Although MAP has been designed to ensure certain standards are met before nations are invited to membership, given the heterogeneity of the group, many candidates failed to meet the MAP requirements. Yet, NATO continued on with its "unfinished business" in Europe.

\section{9: The Turn to the Western Balkans}

Albania, Croatia, and Macedonia first gained membership in assorted Euro-Atlantic institutions in the early 1990s. These three Balkan countries were offered MAP status in 1999. Since then, these countries have conducted reforms of their military forces aimed at reaching NATO standards. After the second round of enlargement, with the integration of seven new members, many allies called for slowing down the rate of NATO expansion. Some allies were concerned about the capability of the Alliance to "digest" an

${ }^{41}$ Larrabee, "NATO Enlargement: Prague and Beyond." 
increasing number of new member states with an unchanged decision-making process. The Balkan states were backed by the U.S., which had launched the U.S.-Adriatic Charter to cooperate more closely on their preparation for future NATO membership. The integration of the Western Balkans into Euro-Atlantic structures was strongly advocated by the southern NATO member states, especially Italy and France. It was seen as an opportunity for the stabilization of the region, as well as a counter-balance to the ongoing eastward enlargement of the Alliance. Basically, three reasons prevailed in favor of giving the green light to Albania and Croatia to start membership negotiations: ${ }^{42}$

- The stabilization of Southeastern Europe was the most important determining factor. Many share an opinion that the integration of the Balkan countries into NATO and the EU will contribute to the stabilization of the whole region, and would like to assure the continuation of the enlargement process to the remaining countries in the region. The fragility of the political situation over the unilateral declaration of independence of Kosovo reminded European members of the Alliance that the region is not completely stabilized, and that NATO presence is still necessary.

- Although it was stressed that those countries had met the MAP requirements, the fact is that these states in the Western Balkans are small countries with relatively modest military capabilities, and as such cannot be significant military contributors to NATO. But a NATO study estimated that this smaller round of enlargement would require only USD 1.5 billion in common funds expenditures over ten years, which was economical in comparison with the estimate for the first round. ${ }^{43}$ The forecast for the cost of the second round of enlargement was about the same amount. Additionally, the proponents of enlargement argued that an increased number of allies brings better budget sharing, maybe modest at first glance, but in the long term beneficial for existing member states.

- Russia, which is always taken into consideration in the debates over NATO enlargement, did not object to this expansion decision.

The third round of enlargement to add Croatia and Albania was not preceded by a great deal of debate. The Alliance gave these states a positive evaluation regarding their implementation of MAP, and Croatia and Albania were invited to join NATO at the summit in Bucharest in 2008. But the Bucharest summit Declaration that began

42 The third country from the group, Macedonia, has faced the so-called "name" problem with its neighbor, Greece. In spite of the fact that the U.S. and the other allies supported Macedonia to get the same status as Croatia and Albania, Greece blocked the decision unless a solution to this lingering bilateral dispute was reached. The core problem is that Greece does not recognize Macedonia under its constitutional name, claiming that it is an old name of part of Greek territory. The UN is supervising current negotiations on this matter. Candidates, CRS Report for Congress, Order Code RL34701 (Washington D.C.: Congressional Research Service, 6 October 2008), 18-19. 
with an announcement that "we met today to enlarge our Alliance" was not so much about enlargement to include states from the Western Balkans. ${ }^{44}$ The real controversial issue - and one that is still pending — is the case of Ukraine and Georgia.

\section{Ukraine and Georgia}

At the NATO Summit in Bucharest the allies decided not to offer an immediate MAP to Ukraine and Georgia, but to begin to contemplate the prospect of membership for the two countries without setting out the clear road map for the process that is normally provided by MAP, which includes annual meetings of the decision-making North Atlantic Council. This decision has created significant confusion, and has resulted in a range of different interpretations. There are a variety of reasons why NATO issued such an ambiguous message. These are rooted in the varied interests of the allies and the Alliance's complicated decision-making process.

The U.S. pushed the allies to offer MAP to Georgia and Ukraine prior to the Bucharest summit. A round of visits by the highest-ranking U.S. officials to Tbilisi and Kiev, including President Bush, were part of their supporting efforts. On the other hand, Russia was very outspoken against the further eastward expansion of NATO. President Vladimir Putin, holding a joint press conference with his Ukrainian counterpart Viktor Yushchenko during his visit to Moscow in February 2008, said that "Russia could aim nuclear missiles at Ukraine if its neighbor and former fraternal republic in the Soviet Union joins the NATO alliance and hosts elements of a missile defense system proposed by the Bush Administration." ${ }^{45}$ This comment was designed to send a very clear message to Georgia (as well as Ukraine), but also to Poland and the Czech Republic, which had decided to host anti-ballistic missile installations designed by the U.S. Nevertheless, U.S. officials kept repeating that Russia has no veto right in NATO, and that the allies - not Russia - would make decisions about NATO enlargement.

That France and Germany had a different opinion became obvious before the summit took place. Both countries named the same reasons: the desire to pursue improved cooperation with Russia and the inability of both Georgia and Ukraine to meet the membership requirements. From the other side, the new NATO member states followed the U.S. in their argument that Europe "whole and free" means the chance for every European country to seek NATO membership.

This discrepancy in the opinions between what the former U.S. Secretary of Defense Donald Rumsfeld called "the new Europe and the old Europe" was clarified by Vladimir Socor as a "revival of traditional European balance-of-power ideas in Berlin and Paris, involving Russian participation in a 'European concert' of equivalent pow-

44 NATO Press Release, "Bucharest Summit Declaration, Issued by the Heads of State and Government participating in the meeting of the North Atlantic Council in Bucharest on 3 April 2008," Bucharest, 3 April 2008.

45 Peter Finn, "Putin Threatens Ukraine On NATO," Washington Post (12 February 2008); available at http://www.washingtonpost.com/wp-dyn/content/article/2008/02/12/AR2008021 201658.html. 
ers. ${ }^{46}$ Socor elaborated that this approach was in line with Russia's call for a "New European architecture," and would lead to the limitation of U.S. influence in Eastern Europe. Furthermore, Russia would once again pull Ukraine and Georgia under its sphere of influence, while Germany would "govern" the eastern part of Europe, and France the Southern one. Socor was speaking in the name of many who have thought that Russia can pursue its interests only playing on the prospect of a divided Europe.

France and Germany revealed their stands publicly before the Bucharest summit, but until the last moment it was not clear what the final outcome would be. The U.S. line was that both countries have to do a lot of work in order to meet the requirements for NATO membership, but that MAP status would provide both Ukraine and Georgia with a clear path to membership without necessarily guaranteeing it. It seems that the declaration was a compromise between divided allies: not to let down the U.S., but also not to grant MAP status.

At the same summit it was decided that further decisions about MAP would be made by the North Atlantic Council at the level of foreign ministers, meaning that it would not be on the agenda of the next NATO Summit in 2009. The North Atlantic Council, which met in December 2008, declared "without prejudice to further decisions which must be taken about MAP, we have agreed that under the NATO-Georgia Commission and the NATO-Ukraine Commission, Annual National Programs will be developed to help Georgia and Ukraine advance their reforms, which will be annually reviewed by the Allies." ${ }^{47}$ Annual National Programs are part of the MAP process through which NATO measures the progress of aspirants with respect to the same five issue areas addressed by MAP. It seems that the allies decided not to have prejudice about the future decision that must be made about MAP, but to have prejudice toward the prospect of membership itself, in contradiction of the idea behind MAP. Memorably, MAP was seen as excluding the direct way to membership, which was in fact revised by the Bucharest decision for Georgia and Ukraine. Thus, the North Atlantic Council's decision has undermined MAP as a mechanism, and has cast doubt on NATO enlargement as a process that is based on defined requirements. Even worse, it divided the allies more sharply than they had been before Bucharest, and left Georgia and Ukraine without any clear message about their membership expectations.

\section{Ukraine and Georgia: Two Different Cases in the Same "Package"}

Ukraine and Georgia are very often considered as part of the "same package" in terms of NATO enlargement. Without question there are similarities in the Euro-Atlantic integration experiences of the two countries. They both were part of the Soviet Union, and gained independence after its dissolution in 1991. Both officially expressed inter-

46 Vladimir Socor, "NATO Debates on Georgia and Ukraine Add Clarity about Russia," Eurasia Daily Monitor 5:64 (3 April 2008); available at www.jamestown.org/single/?no_cache= 1\&tx_ttnews[tt_news] $=33521$.

47 NATO Press Release, "Final Communiqué, Meeting of the North Atlantic Council on the level of foreign ministers held at NATO Headquarters," Brussels, 3 December 2008. 
est in joining NATO in 2002, before their "color revolutions" in 2003 and in 2004. The U.S. has firmly backed the NATO membership aspiration of both countries. In fact, in March 2007 the U.S. Congress ratified the NATO Freedom Consolidation Act, which supports NATO enlargement to the Western Balkans, Georgia, and Ukraine. With U.S. assistance, those two countries have actively engaged in regional initiatives such as GUAM and the Organization for Black Sea Economic Cooperation (BSEC). ${ }^{48}$ Russia considers both Ukraine and Georgia as part of its "near abroad" and "sphere of influence." Both of these countries largely depend on Moscow in terms of energy and commerce, and both of them are important transit countries for the transport of Russian oil and gas. Finally, NATO usually views the processes of Georgia and Ukraine's accession paths as being part of the same agenda.

Despite all these commonalities, however, there are some essential differences between Georgia and Ukraine related to potential NATO integration. First, Ukraine does not face the same explicit territorial challenges as Georgia, which is plagued by problems involving the breakaway republics of South Ossetia and Abkhazia. Second, although Ukraine enjoys relatively secure territorial integrity, its relations with Russia are still sensitive, with several open questions on the table, such as the status of the large Russian-speaking minority in Ukraine, conflicts over natural gas supplies, and the situation in Crimea. Third, after the "Orange Revolution," Ukraine managed to carry on reforms of its political system and move the country from a presidential to a parliamentary system. As a consequence, Freedom House reported in 2006 that Ukraine was a "free" country. In spite of its unstable political situation, Ukraine conducts free and democratic elections, and has made it possible for the opposition to come to power through elections. On the contrary, Georgia has failed to exchange its strong presidential system for a parliamentary model, and is rated by the Freedom House report as a "partly free" country. Fourth, Russia sees Ukraine as a part of its own identity, and considers bilateral relations with Ukraine to be more an element of its "domestic affairs," which is not the case with respect to Georgia. Fifth, public support for ambitions on the part of Ukraine's political elite to join NATO is very low, and reflects the reality of a country that is deeply divided regionally between east and west. In Georgia, public support for NATO accession is very high, as is also the case among the political elite. Finally, NATO had shown more interest in cooperating with Ukraine than with Georgia prior to the "color revolutions." The NATO-Ukraine Commission was launched in 1997, while the NATO-Georgia Commission only began in 2008.

48 GUAM is a regional organization of the four post-Soviet republics Georgia, Ukraine, Azerbaijan, and Moldova launched in 2001. Uzbekistan was a member of the organization until its official withdrawal in 2005, when the organization changed the name from GUUAM back to the previous version. GUAM is widely seen as an attempt of the member states to counter Russian influence in the region. BSEC was launched in 1992 on Ukraine's initiative, aimed at fostering cooperation between Albania, Armenia, Azerbaijan, Bulgaria, Georgia, Greece, Moldova, Romania, Russia, Turkey, and Ukraine, all of which signed the Istanbul Summit Declaration. 


\section{Ukraine}

Ukraine's foreign policy orientation, whether towards the West or towards the East, is one of the most intriguing questions in the relationship between Moscow and Washington. Being an independent parliamentary democracy since the USSR ceased to exist in 1991, Ukraine's foreign policy course has been often ambiguous and unpredictable. Four years after the so-called "Orange Revolution," one might say that this former Soviet Republic has not yet decided about its foreign policy direction. The turning point for this decision might come in January 2010, when presidential elections are scheduled in Ukraine. The election outcome could bring about a shift in the "Western agenda" of the current Ukrainian government should a pro-Russian party prevail. With this prospect in mind, 2009 was seen as the decisive year in terms of undertaking crucial steps on the way to EU and NATO integration. That was likely at least partially the explanation for the excitement over the question of Ukraine's strategic future. The Georgia crisis in August 2008 - followed by the Russian accusation that Ukraine supported Georgia during the war, and the most recent gas crisis - simply highlighted the simmering disputes with Russia regarding Ukraine's NATO aspirations.

Ukraine's location is of strategic importance both for the West and Russia. Ukraine is the second-largest European country, surrounded by four NATO countries (Romania, Hungary, Slovakia, and Poland) and Russia, situated on the Black Sea. In geopolitical terms, Ukraine represents a buffer zone between Russia and NATO. Ukraine is the transit country for Russia's natural gas supply, which covers approximately twothirds of the total European demand for gas.

Ukraine's potential success as a democratic country integrated into Euro-Atlantic structures is widely seen as having a significant impact on the Western regions of the post-Soviet space. The negative view of this importance holds that "if Ukraine fails, it would diminish aspirations of the other countries from the region." 49 On the other hand, Ukraine's membership in NATO for Russia is, as has been very clearly put by the Russian side, "out of question." In order to provide accurate insight into the possibilities of Ukraine's integration to NATO, this section will separately consider Ukraine-NATO relations, Ukraine-Russia relations, and U.S.-Ukraine relations.

Ukraine and NATO. The main constraint in the efforts of the Ukrainian government to gain membership in NATO is the low number of Ukrainians who support such a move. This has been proven by the results of all polls conducted on the subject in the last few years. One poll, conducted in June 2008 by the Fund for Public Opinion, reported that " 55 percent of Ukrainian respondents were against NATO membership, with only 22 percent in favor."

49 "Ukraine Comes to the Forefront; Russia's Western Neighbors," The Economist (13 September 2008).

50 “Ukraine's NATO Accession: Politics as Usual," Central Europe Digest (18 August 2008); available at www.unian.net/eng/news/news-267760.html. 
Nevertheless, Taras Kuzio noticed that "Ukraine's relations with NATO are the most advanced of any of the international organizations that it cooperates with." ${ }^{, 51}$ Both sides have found strategic interest in mutual cooperation. For NATO, it is the strategic position of Ukraine as a buffer zone between Russia and the West. No less important, this former Soviet Republic has the second-largest military in Europe, right after Russia. Given Ukraine's turbulent transitional period, NATO had an interest in exerting an influence on Ukraine's security reform process. Encouraging news for the Alliance came when Ukraine decided to give up its nuclear arsenal in 1992. For Ukraine, close relations with the Alliance were the best way to protect itself from a strong dependence on Russia, and to draw closer to the West. As Kuzio notes, "While economically dependent upon Russia, particularly in the energy field, Ukraine has therefore sought to cooperate politically and militarily with NATO in a multilateral forum and bilaterally with key Western countries such as the U.S. and U.K., ${ }^{, 52}$

Ukraine was the first country of the Commonwealth of Independent States (CIS) to join the Partnership for Peace in 1994. This cooperation was further enhanced by signing the NATO-Ukraine Charter on Distinctive Partnership in July 1997, which established the NATO-Ukraine Commission (NUC). This level of cooperation, which was only offered to two countries-Ukraine and Russia - confirms the special interest that NATO has in Ukraine. In almost every NATO document, starting with the first study on NATO enlargement in 1995, Ukraine was mentioned as a potential NATO member state.

Ukraine's intention to seek NATO membership was declared by then Ukrainian president Leonid Kuchma for the first time in July 2002. Nevertheless, the unsubstantiated allegation of the transfer of a sophisticated Ukrainian defense system to Saddam Hussein's Iraq negatively affected Kuchma's reputation and Ukraine's aspirations for NATO membership.

An Intensified Dialogue on Ukraine's membership aspirations was launched in April 2005, along with "a package of short-term actions ... designed to enhance NATO-Ukraine cooperation in key reform areas: strengthening democratic institutions, enhancing political dialogue, intensifying defense and security sector reform, improving public information, and managing the social and economic consequences of reform. ${ }^{, 3}$ Ukraine proactively cooperates with NATO in many areas. For example, Ukraine is the only Partner country engaged in the four main ongoing NATO-led operations and missions: in Kosovo, Iraq, Afghanistan, and Operation Active Endeavour in the Mediterranean Sea. Ukraine has held annual exercises both at the multilateral NATO level and the bilateral U.S. and U.K. level since 1997.

Successful cooperation in NATO-Ukrainian relations has been overshadowed by the political turmoil in the country. In September 2006, the pro-Russian Ukrainian

51 Taras Kuzio, "Ukraine: NATO Relationship," Research Update for Oxford Analytica (14 April 2000); available at www.ualberta.ca/ cius/stasiuk/st-articles/an-ukr-nat2.htm.

52 Ibid.

53 "NATO's Relations with Ukraine," available at http://www.nato.int/cps/en/SID-A58F8D55D6DF31CF/natolive/topics_37750.htm. 
Prime Minister Victor Yanukovych said it would be disadvantageous to continue with efforts to receive MAP status, given the lack of public support for this step in Ukraine. He slowed down the pace of development of relations with the Alliance, and Ukraine lost momentum in its attempt to draw closer to the West.

At the beginning of 2008, the Ukrainian President, Prime Minister, and Head of the Parliament sent an official letter to apply for the Membership Action Plan. Given the low level of public support for NATO membership in Ukraine, this initiative was based on the agreement between the parliamentary coalition and opposition parties that Ukraine's potential accession in NATO must be decided by a referendum.

Ukraine and Russia. Ukraine became an independent state on 1 January 1992, after the Ukrainian referendum on independence on 1 December 1991. More than 90 percent of the Ukrainian people expressed their support for independence at the referendum, and Leonid Kravchuk was elected as the first president of the country. Diplomatic relations were established between the Russian Federation and Ukraine immediately afterwards.

However, understanding Ukraine today requires an understanding of the long history of Russo-Ukrainian relations. Kievan Rus, the largest and the most influential medieval country in Europe, is considered as a predecessor of both Russia and Ukraine. Kiev, the modern capital of Ukraine, is often referred to as the "mother of Russian cities," or a cradle of Russian civilization. The Kievan Rus disintegrated in the twelfth century, and subsequent to that the territory of Ukraine was divided among a number of regional powers. Finally, in the nineteenth century, the largest part of the country was integrated into the Russian Empire, with the rest being absorbed by the Austro-Hungarian Empire. From 1922 until independence, Ukraine had been a constituent republic of the Soviet Union.

Ukraine's first years of independence were marked by difficult years of transition, economic problems, and inflation. Leonid Kuchma took office in July 1994 and made efforts to stabilize the economic situation, which finally brought results in the late 1990s. Nevertheless, Kuchma was criticized by the opposition for leading the country in an undemocratic manner. The presidential elections in 2004 and the political battle between the Prime Minister Viktor Yanukovych, who claimed victory, and the opposition leader Victor Yushchenko, who opposed the official election results, led to the massive political demonstrations that came to be known as the Orange Revolution. The Ukrainian Supreme Court ordered a second round of elections, which brought victory to the pro-Western candidate Yushchenko. Vladimir Putin, who was the President of the Russian Federation at the time and who openly supported Yanukovych, accused the West of interfering in Ukrainian domestic policy by organizing and actively participating in the Orange Revolution.

A set of unresolved territorial problems burdened bilateral relations between the two countries during the first years of independence. The most important concerned the question of the Crimea, especially the status of the city Sevastopol. The formerly Russian peninsula was given to Ukraine as a "gift" by the secretary-general of the Soviet Communist Party, Nikita Khrushchev, in 1954. As Dmitry Trenin wrote, "Crimea, with 
its close to 70 percent Russian population, a distinctly Russian linguistic environment, and strong historical links to Russia has occupied a very special place in the collective Russian mentality." 54 Although some political circles in Moscow had periodically raised the idea that Sevastopol ought to be a part of Russian territory, Russian President Boris Yeltsin in 1997 signed a treaty of cooperation and partnership with Ukraine aiming to finally determine the border between the two countries. Trenin noted, "The Agreement on the Black Sea Fleet authorizes the leasing to Russia of Crimean facilities rather than territory. In exchange, the Russian Black Sea Fleet gained the right to be present in Crimea for the following twenty years." ${ }^{, 55}$ Although the lease includes a possible extension beyond 2017, Ukrainian President Viktor Yushchenko declared in 2008 that Ukraine is not willing to extend it. Russia has repeatedly stated that it wants to bargain on the issue. The Sevastopol base is very important for Russia because of its strategic location, which provides Russia access to the Mediterranean Sea. In many opinions, Russia has no alternative to the Sevastopol base. ${ }^{56}$ One could expect this question to recur again as a problematic issue in the bilateral relations of the two countries.

Trenin sees the matter of identity, not territorial issues, as the core problem between the two countries. "The initial political choice ('Ukraine is not part of Russia'), [which was] essentially negative, was comparatively easy to make and, surprisingly to many, also to carry out. The positive choice ('Ukraine is a part of Europe') was even easier to make, but it was extremely difficult to realize. Right now, Ukraine is caught between the two: it is no longer part of Russia, but not yet - and this is a long yet - part of organized Europe." ${ }^{57}$ In order to explain the level of complexity surrounding Ukraine-Russia relations, Trenin acknowledged that, "for Ukrainians, independence means independence from Russia. It was thus natural, although unpleasant, to start constructing Ukrainian identity in opposition to Russia's." $" 58$

In 2005, nearly two-thirds of Ukrainian adults were critical of the collapse of the USSR, but at the same time, half were content with the emergence of an independent Ukraine as a result of this collapse. Additionally, "only 19 percent viewed both events as positive and 23 percent negatively, which means that nearly one-half ( 42 percent) have inconsistent opinions on this matter." ${ }^{, 59}$ These contradictory findings of a Ukrainian public opinion survey conducted by Warsaw University in 2005 revealed some of

54 Dmitry Trenin, The End of Eurasia: Russia on the Border between Geopolitics and Globalization (Washington D.C.: Carnegie Endowment for International Peace, 2001), 165.

55 Ibid., 167.

56 For more details, see "Russia Has no Alternative to Sevastopol Base-Naval Expert," GlobalSecurity.org (20 January 2009); available at www.globalsecurity.org/wmd/library/ news/russia/2009/russia-090120-rianovosti01.htm.

57 Trenin, The End of Eurasia, 170.

58 Ibid., 163.

59 Joanna Konieczna, Ukraine after the "Orange Revolution": Changes in the Social Attitudes and Values, CES Report (Warsaw: The Centre for Eastern Studies, April 2006), 60; available at www.res.ethz.ch/kb/search/details.cfm?lng=en\&id=105402. 
the complexities of Ukraine's political reality. Ukraine is strongly divided in two parts: western Ukraine, with a predominantly pro-Western orientation, and eastern Ukraine, which is slanted toward Russia. Some analysts fear that the inability of the political elite to take a balanced approach to Ukraine's foreign policy and current financial crisis could even lead to a disintegration of Ukraine as a sovereign country.

The disputes over the deliveries, volumes, prices, and transit terms of natural gas supplies from Russia to Ukraine have been spotlighted as a problem with grave political and economic implications for many European states since 2005. Although a history of gas problems has been ongoing since the dissolution of the Soviet Union, the turning point was the Russian request to Ukraine to pay market price for Russian gas in 2005. Until that year, Ukraine paid USD 50 per 1,000 cubic meters of gas, much less in comparison with the global market price, which was around USD 160. That request posed a potentially huge impact on the Ukrainian economy, due to the fact that Ukraine consumes 24 billion cubic meters of Russian gas annually. Ukraine is the sixth-largest consumer of natural gas in the world, while its per capita GDP is only slightly above fiftieth worldwide. ${ }^{60}$ Peter Zeihan, a Stratfor analyst, sees two reasons for the shift in Russian energy policy: first, it was a signal to the new Ukrainian government after the Orange Revolution of Moscow's feelings about Kiev's Western orientation; second, an economically resurgent Russia could tolerate a momentary loss in natural gas income. ${ }^{61}$ The problem culminated in January 2006, when Russia cut off gas supplies to Ukraine. The supply was restored in the next few days, followed by an agreement between the two states. Yet a new crisis broke out in early 2009, as a consequence of the failure of the two states to reach an agreement about new gas prices. Given that Europe imports one-quarter of all its gas from Russia, and approximately 80 percent of that gas travels in pipelines across Ukraine, many European countries were held hostage by the Russian-Ukrainian conflict and suffered problems caused by a midwinter cut-off in gas supplies.

Taras Kuzio reflects that "the most visible domestic restraint upon Ukraine's security policy is its interdependence with Russia and CIS in economic and energy policies." ${ }^{, 2}$ Furthermore, he notes that "the main manner in which Ukraine will lessen its dependence on Russian energy supplies will be twofold: first, by improving its domestic economy and being able to pay for energy import; second, through energy conservation." ${ }^{63}$ After almost twenty years of independence, Ukraine has managed to deal successfully with neither of Kuzio's two recommendations.

${ }^{60}$ Valentinas Mite, "Ukraine: Would Hike in Russian Gas Prices Prove a Blessing in Disguise?" Payvand's Iran News (14 July 2005); available at www.payvand.com/news/05/jul/ 1110.html.

61 Peter Zeihan, “The Russian Gas Trap,” Stratfor Global Intelligence (13 January 2009); available at www.stratfor.com/weekly/20090113_russian_gas_trap.

62 Taras Kuzio, "The Domestic Sources of Ukrainian Security Policy," The Journal of Strategic Studies 21:4 (December 1998): 23.

${ }^{63}$ Ibid. 
Ukraine and the United States. "Ukraine obviously is a very important partner for the United States and a good friend. We have long believed that Ukraine's independence, its democracy, is essential to a Europe whole and free and at peace." ${ }^{64}$ With these words, U.S. Secretary of State Condoleezza Rice opened the signing ceremony for the United States-Ukraine Charter on Strategic Partnership and Security in December 2008. This charter is an extension of the "strategic relations" between the two countries that started with the independence of Ukraine in 1991. The charter outlines the importance of deeper bilateral cooperation in defense and security, energy security, economics and trade, democracy, people-to-people contacts, and cultural exchanges.

Although labeled as "strategic relations" in the period of the late 1990s, which Ukrainian scholar Taras Kuzio called the "golden era of U.S.-Ukrainian relations," 65 one might see various stages in the history of bilateral relations between the two countries. According to Volodymyr Dubovyk from Odessa National University, the U.S. did not have any special interest in Ukraine immediately after the end of the Cold War. "The search for a new global role for the United States had been launched, and the post-Soviet dimension of its foreign policy was merely one of many, and no longer the priority." ${ }^{\circ 6}$ Dubovyk reflects that the United States was interested only in the question of the disposition of the nuclear arsenal inherited from the USSR. "Former president George H.W. Bush's 'Chicken Kiev' speech in August 1991, cautioning Ukrainians against 'suicidal nationalism' just a few weeks before Ukraine declared its independence, was the manifesto for his administration's policy toward the Soviet Union." ${ }^{\circ 7}$

The "golden era" started with the first Kuchma's presidency (1994-2000). The trilateral agreement between Ukraine, Russia, and the United States on nuclear energy and disarmament was signed in January 1994. Ukraine became the third-largest recipient of U.S. aid, right after Israel and Egypt. According to Taras Kuzio, "A worldwide survey by the Washington-based Pew Global Attitudes Project found that of the six post-communist states surveyed, the Ukrainians had the most favorable opinion of the United States ( 80 percent), with Poland coming second at 79 percent.",68

The downturn in U.S.-Ukrainian relations took place with Kuchma's reelection as president of Ukraine in 1999. Kuchma appeared more inclined to neglect democratic standards of governing in his second term. "Ukraine received a litany of bad reports from Western think tanks (Freedom House, Amnesty International, Helsinki Watch),

${ }^{64}$ U.S. Secretary of State Condoleezza Rice, "Remarks at the Signing Ceremony for the United States-Ukraine Charter on Strategic Partnership and Security," 19 December 2008; available at http://merln.ndu.edu/archivepdf/EUR/State/113394.pdf.

65 Taras Kuzio, "U.S.-Ukrainian Relations Return to 'Golden Era," Ukrainian Observer (May 2006); available at www.taraskuzio.net/media7_files/international-Golden_Era.pdf.

66 Volodymyr Dubovyk, "U.S.-Ukraine Relations, The Long Road to Strategic Partnership," PONARS Policy Memo No. 424 (Washington, D.C.: Center for Strategic and International 67 Studies, December 2006); available at www.csis.org/media/csis/pubs/pm_0424.pdf. Ibid.

68 Taras Kuzio, "U.S.-Ukrainian Relations Will not Revive under Kuchma," Kyiv Post (13 March 2003); available at www.taraskuzio.net/media21_files/us_ukraine.pdf. 
international organizations (Council of Europe, EU) and governments (the U.S. State Department). The question of media freedom had already damaged Ukraine's reputation even before the murder of opposition journalist Georgy Gongadze in the fall 2000. ${ }^{, 69}$ Kuchma's regime was associated with affairs and scandals. After 11 September 2001, the U.S. was more focused on cooperation with Russia in the fight against terrorism, and its emphasis on strategic partnership with Ukraine was watered down for some time.

The regime change in Kiev that brought to power the Western-oriented president Victor Yushchenko was warmly welcomed by the West. As noted above, Russia is of the mind that this regime change happened because of alleged heavy U.S. interference in Ukrainian domestic policy. ${ }^{70}$ Regardless of Russia's opinion on the Yushchenko election, the U.S. has continued to support Ukraine's Euro-Atlantic aspirations. Nevertheless, the most serious obstacles to the development of a coherent foreign policy in Ukraine are the mixed messages that have been sent from the most important political parties. The second problem is the relatively slow development of the EU's support for the Ukrainian integration process. Although the Ukrainian government might count on higher levels of public support for integration into the EU rather than to NATO, five years after the Orange Revolution Ukraine has still not been considered for EU membership. According to the Ukrainian representatives, the European Neighborhood Policy was not an adequate political instrument. ${ }^{71}$ The Eastern Partnership ${ }^{72}$ - the most recent EU mechanism to be developed - has yet to prove its relevance in practice, but it still treats Ukraine as a "neighboring country." Given the difficulties in relations between Ukraine on the one hand and NATO and the EU on the other, one might conclude that the United States remains the most reliable link between Ukraine and the West.

\section{Georgia}

Georgia, together with Armenia and Azerbaijan, is part of the South Caucasus region located along the line that separates Asia and Europe. It makes Georgia's position

${ }^{69}$ Ibid.

70 Others are of a contrary opinion - namely, that Russian agents were behind the apparent attempt to poison Yushchenko with dioxin during his campaign for president. The matter has never been solved, and the allegations have never been substantiated.

71 The European Neighborhood Policy, launched in 2004, applies to the EU's immediate neighbors by land or sea: Algeria, Armenia, Azerbaijan, Belarus, Egypt, Georgia, Israel, Jordan, Lebanon, Libya, Moldova, Morocco, Occupied Palestinian Territory, Syria, Tunisia, and Ukraine. It is based on bilateral relations between each country and the EU, and is designed to be clearly distinct from the EU enlargement process. For more details see http://ec.europa.eu/world/enp/policy_en.htm.

72 The Eastern Partnership is an EU program launched in March 2009 involving six former Soviet republics: Ukraine, Moldova, Azerbaijan, Armenia, Georgia, and Belarus. The aim of this initiative is to foster relations between the EU and its eastern neighbors, similar to the model for Mediterranean Union. For more detail, see http://ec.europa.eu/external_relations/ eastern/index_en.htm. 
strategically important, but difficult at the same time. Georgia's territory, with its outlet to the Black Sea, is an essential part of the strategic route that connects Europe and Asia via the Bosporus and the Dardanelles, the two straits that form the shortest maritime link between the two continents. Georgia is strategically important for gas and oil transit from producing countries in Central Asia to the European market. In military terms, the Black Sea is vital to any attempt at force projection in the region. Given the geographical configuration of the terrain, the best route for an attack on Russia from the south leads through the Black Sea. As an invasion of Russia nowadays looks highly unlikely, the control that Georgia's terrain offers over the transportation of natural gas is perhaps its most salient geostrategic quality. To briefly illustrate: Russia supplies 36 percent of Germany's gas needs, 20 percent of France's, 25 percent of Italy's needs, 100 percent of Georgia's, 66 percent of Ukraine's, and 64 percent of Turkey's. ${ }^{73}$

Georgia is bordered by one NATO member state (Turkey) and by Armenia, Azerbaijan, and the Russian Federation. Georgia is currently experiencing a highly unstable political situation, with growing opposition to the firm political style of governance of the president, Mikheil Saakashvili. However, potential early elections in Georgia would not create the dilemma that Ukraine is facing, having to choose whether to turn to the West or the East. Georgia is firmly oriented toward the West, but given the challenges that currently face this country, the real question is how far it can presently move in a Western direction. Taking into account the main factors that have a decisive effect on the possibility of Georgia's accession to NATO, this section will separately consider NATO-Georgian relations, Russian-Georgian relations (with a special focus on the August 2008 conflict), and U.S.-Georgian relations.

Georgia and NATO. The main constraint in the efforts of the Georgian government to gain membership in NATO is the problem of Georgia's territorial integrity. According to Article 5 of the Washington Treaty, the lack of secure and clear integrity of a nation's territory is an almost insurmountable obstacle to accession to membership. Georgia has had problems with two breakaway provinces, South Ossetia and Abkhazia, since its independence in 1991. Prolonged tensions culminated in August 2008 in an armed conflict between Georgia and Russia, with Russian troops advancing well into Georgia, and led to Russia's recognition of the independence of South Ossetia and Abkhazia.

Regarding Georgia's future in NATO, Oksana Antonenko noted it is only a small number who do not see that Article 5 of the North Atlantic Treaty presents huge difficulties for Georgia's accession to NATO. ${ }^{74}$ The 1995 "Study on NATO Enlargement" reemphasized that territorial integrity is a crucial requirement for membership. As Pal Dunay stressed, "the Alliance was relatively forthcoming and left no doubt about the following: 1) It did not want to import conflicts and instability into the alliance. There-

73 Paul Rivlin, "Russia's Invasion of Georgia: Strategic Implications," TelAvivNotes (20 August 2008); available at www.dayan.org/Russia's\%20Invasion\%20of\%20Georgia.pdf.

74 Oksana Antonenko, “A War with No Winners," Survival 50:5 (October-November 2008): 23-36. 
fore, countries with pending ethnic or external territorial disputes, including irredentist claims or internal jurisdictional disputes must settle them by peaceful means in accordance with OSCE principles. 2) Enlargement will be decided on a case by case basis." ${ }^{" 75}$ According to the American scholar Richard Betts, Georgia's aspiration for NATO membership was controversial even before the August crisis:

\begin{abstract}
Russian support for [the] secession of Georgia's breakaway provinces was well established before the August engagement. What were they (the Bush Administration) thinking? That the breakaway regions would voluntarily reintegrate with Georgia before the country was admitted to NATO? That Georgia would regain the territories without Russian intervention? That Georgia would be admitted without two separatist regions and NATO would add a codicil to admission that its defense guarantee excluded them? Impossible. ${ }^{76}$
\end{abstract}

Nevertheless, relations between Georgia and NATO have become very intensive in the last few years, representing a significant increase in the level and quality of interaction over the state of the relationship in the 1990s. Within the framework of the Euro-Atlantic Partnership Council (EAPC), as Martin Malek has noted, in 1999 only one specialized ad hoc Working Group was established on the Prospect for Regional Cooperation in the Caucasus. ${ }^{77}$ Malek observed that NATO has never formulated a comprehensive approach to cooperation with the South Caucasus, nothing even similar to its concept of special relations with Russia and Ukraine or the Mediterranean Dialogue. In 2002, NATO Secretary-General Lord Robertson stated that, "for the North Atlantic organization, the Caucasus is of no special relevance." ${ }^{, 78}$ However, the Alliance became more interested in the South Caucasus after 11 September 2001. As Stephen Larrabee reflected, the Caucasus and Central Asia as regions have had growing strategic importance for the West in light of the war on terror. ${ }^{79}$

The first major Georgian step toward NATO membership, after joining PfP in 1994, was President Eduard Shevardnadze's participation at the NATO Summit in Prague in 2002, upon NATO's invitation. The Georgian position regarding its NATO

75 Pál Dunay, "From Obsession to Oblivion: Reconceptualization of Security in NATO since 1990," in Globalization and Environmental Challenges: Reconceptualizing Security in the 21 st Century, eds. Hans Günter Brauch, Úrsula Oswald Spring, Czeslaw Mesjasz, John Grin, Pál Dunay, Navnita Chadha Behera, Béchir Chourou, Patricia Kameri-Mbote, and P.H. Liotta (New York: Springer, 2007), 718.

76 Richard K. Betts, "The Three Faces of NATO," The National Interest Online (10 April 2009); available at www.nationalinterest.org/Article.aspx?id=20944.

77 "The Group had focus on defense and economic issues, civil and emergency planning, science and environmental cooperation, and information activities." For more detail, see Martin Malek, "NATO and the South Caucasus: Armenia, Azerbaijan, and Georgia on Different Tracks," Connections: The Quarterly Journal 7:3 (Summer Supplement 2008): 30; available at https://consortium.pims.org/nato-and-the-south-caucasus-armenia-azerbaijan-and-georgiaon-different-tracks.

Ibid.

79 Stephen Larrabee, NATO's Eastern Agenda in a New Strategic Era (Santa Monica, CA: RAND Corporation, 2003), 173. 
aspirations has been very clear both before and after the regime change in 2003, but in Prague Shevardnadze announced for the first time publicly that Georgia was actively seeking membership in NATO. Yet the Intensified Dialogue with the Alliance only started with Georgian President Mikheil Saakashvili after the so-called "Rose Revolution" in November 2003. The Alliance appointed its first Special Envoy for the South Caucasus and Central Asia, Robert Simmons, in 2004. Georgia was offered Intensified Dialogue status in September 2006.

As mentioned, NATO's declaration at its Bucharest summit reiterated its commitment to enhancing cooperation with Georgia, and included a pledge that Georgia will eventually become a NATO member, without specifying a time framework or a road map. The NATO-Georgia Commission ${ }^{80}$ was established in September 2008, as the Alliance stated, "without prejudice to [any] further decision which must be taken about MAP." ${ }^{\prime 1}$ Although the August 2008 crisis made the situation regarding Georgia's NATO aspirations more complicated, Georgian Foreign Minister Grigol Vashadze claimed that "the NATO-Georgia commission is an alternative and equally viable path to NATO as the membership action plan, sometimes called MAP." ${ }^{\prime 2}$

With regard to the August crisis, NATO reacted primarily at the rhetorical level. It condemned Russia's "disproportionate military action in Georgia," and suspended "business as usual" with Russia, including formal meetings at the high level of the NATO-Russia Council. ${ }^{83}$ Relations were formally resumed in March 2009. This tepid response caused many critics to conclude that NATO is a "paper tiger," incapable of protecting its partners.

At the foreign ministerial meeting of the North Atlantic Council held in Brussels, on 2-3 December 2008, NATO reiterated its Bucharest commitment to future Georgian membership, and declared that "both counties [Ukraine and Georgia] have made progress, yet both have significant work left to do." ${ }^{, 4}$ A similar commitment was reiterated at the NATO Summit in Strasbourg and Kehl in April 2009.

In spite of the often negative image that NATO faces in some membership-seeking countries, the situation in Georgia seems to be the opposite. An advisory referendum on whether to join the Alliance was held on 5 January 2008 and, according to the offi-

80 "The NATO-Georgia Commission was established in September 2008 for the purpose of deepening the political dialogue between NATO and Georgia and to supervise the process set in hand at the Bucharest Summit in view of Georgia's membership aspiration." See: NATO, "Framework document on the establishment of the NATO-Georgia Commission," available at www.nato.int/docu/pr/2008/p08-114e.html.

81 NATO Press Release, "Final communiqué, Meeting of the North Atlantic Council at the level of foreign ministers held at NATO Headquarters," Brussels, 3 December 2008.

82 "US Offers Georgia Road Map for Deeper Ties," The Guardian (10 January 2009); available at www.guardian.co.uk/worldlatest/story/0,,-8229175,00.html.

83 For more details, see "NATO's Relations with Russia" on the NATO website, at www.nato.int/issues/nato-russia/topic.html.

84 NATO Press Release, "Final communiqué, Meeting of the North Atlantic Council at the level of foreign ministers held at NATO Headquarters," Brussels, 3 December 2008. 
cial results of the Central Electoral Commission, 68.4 percent of the total turnout was in favor of NATO membership. ${ }^{85}$

In order to meet membership requirements, Georgia has intensively worked on the reform of its security sector in accordance with NATO standards, with significant allocations of GDP going to the military budget. ${ }^{86}$ Yet both sides admit that democratic civilian control over the security sector in Georgia is still not at the required level. One of the reasons for this failure is the unstable political situation in the country, much of which is due to its strong presidential system of governance. In 2007, NATO Secretary-General Jaap de Hoop Scheffer expressed his concerns about the state of democracy in Georgia: "The military alliance was following closely and with concern the events in Georgia. The imposition of emergency rule, and the closure of media outlets in Georgia, a partner with which the alliance has an intensified dialogue, are of particular concern and not in line with Euro-Atlantic values." ${ }^{87}$

Finally, it is very important for NATO-Georgia relations that Georgia is able to be an effective contributor to NATO's peacekeeping operations. Saakashvili explained this importance thus: "Georgia wants to be a producer of security. That is why our troops are deployed in peace support operations in Iraq - and in NATO operations in Kosovo and Afghanistan." ${ }^{, 88}$ On many different occasions NATO representatives have mentioned that the Alliance deeply appreciates Georgia's responsible attitude toward participation in peacekeeping operations.

Georgia and Russia. Georgian-Russian relations are very complex, and are burdened with a long history of both conflict and cooperation, but it seems that the disagreement has become sharper over the question of Georgia's accession to NATO. To briefly review the recent history, at the beginning of the nineteenth century, Georgia became a part of the Russian Empire. A period of independence following the Russian Revolution in 1917 did not last long; Georgia was incorporated into the Soviet Union in 1922, and regained independence in 1991, after the collapse of the USSR. As was the case in many post-communist countries, Georgia faced a traumatic transitional period during the 1990s marked by economic problems and internal unrest. Under its first president, Zviad Gamsakhurdia, Tbilisi tried to assert authority over Abkhazia and South Ossetia, two Georgian provinces that had had autonomous status within the Soviet Union. After a civil war in 1992-93, Russian-dominated peacekeeping operations were established both in South Ossetia and Abkhazia, monitored by the OSCE and the

85 Malek, "NATO and the South Caucasus," 36.

86 "Georgia had a massive defense modernization program with a very fast growing military budget (risen by 30 times over the past seven years reaching \$1 billion in 2007)." Alexey Muraviev, "Georgia: The Broader Geostrategic Considerations," Defence and Foreign Affairs Strategic Policy 36 (July/August 2008): 11.

87 "Georgia: After Crackdown on Protests, President Calls Early Polls," Radio Free Europe/Radio Liberty (8 November 2007); available at http://www.rferl.org/content/article/ 1079100.html.

88 Mikheil Saakashvili, “Georgia's Role in International Security Policy," Hampton Roads International Security Quarterly (April 2006): 5. 
UN. The situation in these areas was relatively stable until the Rose Revolution in 2003. Although Mikheil Saakashvili managed to solve secessionism in another breakaway province, Adjaria, in the fourth month of his mandate, the situation with Abkhazia and South Ossetia remained tense, and finally culminated with an armed conflict between Georgia and Russia that started on 7 August 2008. The five-day-long war was ended by a cease-fire brokered by French President Nicolas Sarkozy.

This article will not offer a detailed examination of the roots and chronology of the Georgian crisis, but the consequences of the crisis are relevant for the research questions being addressed here. Oksana Antonenko argues that, although it is too early for a clear assessment of the consequences of the conflict, it can be described as a "war with no winners." In her opinion, it is clear that Georgia has lost both Abkhazia and South Ossetia, and has endangered its chances of eventually joining NATO. The future integration of Abkhazia and South Ossetia into the international community also does not look promising. Russia's position in the region was weakened, and its actions further reduced the appeal of Russian-led institutions, like the Commonwealth of Independent States. ${ }^{89}$

The Georgian crisis gave rise to many controversies. Many scholars have assumed that it is just one part of a wider conflict between Russia and the West, which is very close to Russia's official political position. Alexey Muraviev wrote that "it was not a war between Russia and Georgia; it is a proxy conflict between Russia and the U.S. over a vital area." 90 Many questions are still unanswered: Who started the war? For what reason? Was the conflict previously planned by Russia as a "tit-for-tat" response to Western attitudes toward Kosovo and Metohija? How should the West respond to Russia for the disproportionate scale of its response in Georgia? In particular, the personal contribution of the Georgian president to the escalation of an internal territorial problem to a regional war is still being researched. One occasionally hears that politicians from the West view Saakashvili as a "gambler who lost the game." In addition, the Georgian opposition-recently reinforced with several of Saakashvili's former close associates ${ }^{91}$ - has called for his resignation, blaming him for losing Abkhazia and South Ossetia.

As Fyodor Lukyanov, editor-in-chief of Russia in Global Affairs, wrote, the Russian side feels that "the Georgian attack against South Ossetia and the world reaction to Russia's response have created a new mood in Russian politics and public opinion." ${ }^{92}$ Alexander Lukin has proclaimed that it marked the end of the post-Soviet phase in

89 Antonenko, "A War with No Winners," 32-34.

90 Muraviev, "Georgia: The Broader Geostrategic Considerations," 11.

91 For more details, see "Georgian Opposition Leader Launches New Party," VOANews.com (23 November 2008); available at http:/wwwl.voanews.com/english/news/a-13-2008-11-23voa13-66604247.html?CFTOKEN=94657791\&jsessionid $=00308 \mathrm{a} 683733 \mathrm{fffb} 1 \mathrm{c} 5853381 \mathrm{fl} 3$ $5 \mathrm{a} 18241 \mathrm{~b} \& \mathrm{CFID}=94669713$.

92 Fyodor Lukyanov, "Two Crises on the Way to Reshaping the World," Russia in Global Affairs (October-December 2008), http://eng.globalaffairs.ru/numbers/25/1234.html. 
Russian foreign policy. From now on, he argues, foreign policy will be neither anti- nor pro-Western, and Russia will have to formulate its own objectives. ${ }^{93}$

In early September 2008, Russian President Dmitry Medvedev formulated five main principles of Russian foreign policy. Put simply, the substance of the so-called Medvedev Doctrine includes the following points:

- The primacy of the fundamental principles of international law

- The world should be multipolar

- Russia should seek no confrontation with any other country, but it also has no intention of self-isolation

- Russia is committed to protecting the lives and dignity of Russian citizens, wherever they may be

- There are regions in which Russia has privileged interests. ${ }^{94}$

It should be kept in mind that Russia had already been anxious about the U.S. plan to deploy an anti-ballistic missile defense system in the Czech Republic and Poland (a plan that was cancelled by the Obama Administration in September 2009), and by the development of the situation regarding the status of the Serbian breakaway province Kosovo and Metohija. Doubts regarding the West's intentions to develop honest relations with Russia were a common phenomenon in this country. In line with this skeptical stance, Russian Foreign Minister Sergei Lavrov asked whether "the past imperative of ensuring a U.S. presence in Europe, while excluding Russia and blocking Germany's rise, remained valid?" ${ }^{95}$ That was the reason why Russia refused to negotiate directly with Tbilisi over the conflict in August 2008. The Kremlin believes that Saakashvili would not have initiated any action, including an attack on the Russian peacekeepers in South Ossetia, without prior U.S. approval. Instead of speaking with then-presidents Saakashvili and Bush, the Kremlin was waiting for the Obama Administration to negotiate many open questions between the two countries; the question of Georgia was considered to be just one among the many.

Georgia and the United States. The United States and Georgia both declare that relations between the two countries are based on shared values of democracy, security, and economic prosperity. The two states signed a bilateral Charter on Strategic Partnership on 9 January 2009 with the aim to increase cooperation in defense, trade, energy, and other areas. ${ }^{96}$ State Department officials stress that the charter is not a mutual

93 Alexander Lukin, "From a Post-Soviet to a Russian Foreign Policy," Russia in Global Affairs (October-December 2008), http://eng.globalaffairs.ru/numbers/25/1239.html.

94 "Geopolitical Diary: The Medvedev Doctrine," Stratfor (2 September 2008); available at www.stratfor.com/geopolitical_diary/geopolitical_diary_medvedev_doctrine.

95 Sergei Lavrov, "Containing Russia: Back to the Future?" Russia in Global Affairs (OctoberDecember 2007); available at http://eng.globalaffairs.ru/numbers/21/1147.html.

96 U.S. Department of State, "United States-Georgia Charter on Strategic Partnership," 9 January 2009; available at www.america.gov/st/texttrans-english/2009/January/20090109145313 eaifas0.2139093.html. 
defense treaty, but they do say it is a highly visible sign of U.S. support for Georgia in the aftermath of its conflict with Russia in August 2008.

The agreement provides a road map for bilateral cooperation between the two countries, and includes the provision of U.S. assistance to Georgia's military to help that country qualify for NATO membership. The agreement is an extension of the very high level of U.S. support for Georgia. As George Friedman asserted, the U.S. "maintain[s] about 130 military advisers in Georgia, along with civilian advisers, contractors involved in all aspects of the Georgian government and people doing business in Georgia." 97

The United States' official discourse regarding its political approach toward Georgia is rooted in the spread of democracy. Georgia is portrayed as a small and fragile but democratic country in the South Caucasus, surrounded by big and hostile (and less democratic) neighbors. This rhetorical line was particularly stressed after Georgia's armed conflict with Russia, as reflected in this statement from the White House: "U.S. assistance will aid Georgia's economy and seeks to ensure Georgia regains its position as one of the world's fastest growing economies. Georgia's economy grew by 12 percent in 2007, as a result of solid macroeconomic management, openness to trade and investment, and business-friendly economic policies. The United States is committed to assisting Georgia to remain on this path and will help Georgia's economy recover from conflict." 98 Although promoting the spread of democracy in Georgia, starting with significant support for the "Rose Revolution," the U.S. failed to react to Saakashvili's sharp conflict with the Georgian political opposition in 2007. According to Freedom in the World 2009, the annual survey of global political rights and civil liberties published by Freedom House, Georgia is still on the list of "partly free" countries. ${ }^{99}$

In December 2008, U.S. military experts who had been engaged in Georgia gave a highly critical classified Pentagon assessment regarding the process of Georgia's security sector reform. The part of the report that was made available to the New York Times states: "The Georgian military, which was routed in August during a brief war with Russia, suffers from widespread mismanagement and unqualified leadership, and is in need of extensive reforms to become a modern fighting force." 100 Furthermore, the report emphasized that, "after more than a decade of American training and nearly five

97 George Friedman, "Georgia and the Balance of Power," The New York Review of Books 55:14 (September 2008): 25.

98 White House Press Release, "Fact Sheet: U.S. Support for Georgia; The United States Supports the Recovery, Stability, and Continued Growth of Georgia's Economy" (Washington, D.C., 3 September 2008); available at www.whitehouse.gov/news/releases/2008/09/ 20080903-6.html.

99 Freedom House, "Freedom in the World 2009 survey release," January 2009; available at www.freedomhouse.org/template.cfm?page $=445$.

100 "Georgia Lags in Its Bid to Fix Army," New York Times (17 December 2008); available at www.nytimes.com/2008/12/18/world/europe/18georgia.html. 
years of heavy investment by president Saakashvili, Georgia's military remains immature and ill prepared." $" 101$

The strong U.S. support for Georgia's Euro-Atlantic integration has already been addressed above. Apart from the official U.S. explanation, there are different thoughts about the motives behind its policy toward Georgia. One explanation is related to energy. The United States has helped to establish Georgia as a major energy transit corridor, building an oil pipeline from the Caspian basin to Turkey, known as the BTC (Baku-Tbilisi-Ceyhan) pipeline, and a parallel natural gas pipeline. Both projects are designed to avoid the more logical (but more politically complicated) geographical routes through Russia or Iran. ${ }^{102}$ There is one view that holds that in Georgia the U.S. found a reliable ally in the region that has become strategically more important in light of the fight against terrorism. Some would say that Georgia's accession to NATO membership is the most efficient way to "contain" Russia.

The factors that connected Georgia so closely to the U.S. are at the core of the currently deadlocked situation. Georgia's strong pro-Western orientation has not brought good results. The issue of territorial integrity remains an obstacle for NATO membership, while Georgia's territorial position is the main obstacle to its accession to EU membership. As is the case with Ukraine, the EU treats Georgia as a "neighboring country" to Europe through ENP and the Eastern Partnership, not as a potential member. To achieve its political goals and to counter strong Russian influence, Georgia sees the U.S. as its most reliable Western ally. And it must be said Georgia is a very committed ally of the U.S., one that participates in U.S.-led military operations even though it is not a member of NATO. In addition to the 300 Georgian soldiers in Iraq that had been sent by former president Eduard Shevardnadze, Mikheil Saakashvili sent an extra 1700 troops when he took office. Thus, Georgia increased its troop strength in Iraq by more than 500 percent, even as other countries in the U.S.-led multinational force were pulling out. In 2005, before the visit of U.S. President George W. Bush to Georgia, one of the main streets of Tbilisi was named after him.

All of the linkages discussed above are based on the policy of the Bush Administration. It is still too early to assess the Obama Administration's policy towards Georgia, but it has clearly made an effort to achieve a more balanced approach both towards Georgia and Russia. In this light, U.S. Secretary of State Hillary Clinton announced that "it was time for NATO to make a new start with Russia," but "urged the alliance to leave open the door to membership for former Soviet states Ukraine and Georgia."103

\footnotetext{
101 Ibid.

102 Michael Klare, "Russia and Georgia: All About Oil," Foreign Policy in Focus (13 August 2008); available at www.fpif.org/articles/russia_and_georgia_all_about_oil.

103 "Hillary Clinton: NATO Must Make Fresh Start with Russia," Reuters (5 March 2009); available at www.huffingtonpost.com/2009/03/05/hillary-clinton-nato-must_n_172068.html.
} 


\section{Conclusions}

The process of NATO enlargement will most likely continue. It seems that the Alliance will extend offers of membership to the states of the Western Balkans: almost certainly to Macedonia, very likely to Montenegro, and possibly also to Bosnia and Herzegovina and Serbia. NATO would definitely also appreciate the integration of the neutral and non-aligned European countries as NATO members, such as Sweden and Finland, bearing in mind their geostrategic importance. However, the main question that this article set out to address - the likelihood of NATO's enlargement to Ukraine and Georgia - is hard to answer. This matter involves delving deep into issues within the complex relations between allies, in relations between both NATO as an organization and its member states on the one side and Russia on the other and in the relations between Ukraine and Georgia with all the players mentioned above. Although this article does not have either the ambition or the competence to predict the future, the overall conclusion is that the prospect for Ukrainian and Georgian membership in NATO is not bright at present, but it is not completely extinguished.

There are at least three reasons that the possibility of these two nations joining the Alliance is still somewhat viable:

1. The pending dispute among the allies about the two aspirants. NATO is an alliance based on consensus decision making, and it is not illogical to presume that the national interests of twenty-eight member states will not always be compatible. The willingness of the allies to compromise in order to preserve NATO's unity has prevailed thus far. The issue of including Georgia and Ukraine within the Alliance has different importance for different member states, but it is not seen as being central to the raison d'etre of NATO. It is not probable that the Alliance will fall apart because of this disagreement, especially knowing that all the allies agreed in Bucharest in April 2008 to promise prospective membership to those states. We may presume that the ambiguous language of that pronouncement left the door open not just for Ukraine and Georgia, but also for the continuation of negotiations among the allies about further rounds of enlargement. NATO is also liable to respect its own decision. If the allies still see NATO as the main instrument of transatlantic collective security, they will find a way to remain banded together, and to save the credibility of the Alliance.

2. Russia's resistance. This article has elaborated many aspects of Russia's hostility not necessarily toward NATO enlargement as such, but certainly toward its eastward dimension. It is difficult to assess how far Russia is willing to go to prevent the potential membership of Georgia and Ukraine in NATO, but recent events show that Russia is now prepared to do more than just grumble as it formerly did. Certainly, if NATO wants to prevent the escalation of hostility with Russia, every additional step that is taken regarding Georgian and Ukrainian membership plans will have to take into consideration Russia's interests as such. 
3. Insufficient preparedness of Ukraine and Georgia to meet membership requirements. Both Georgia and Ukraine have their own internal obstacles in the way of their ambitions to gain membership in the Alliance. The lack of domestic support for NATO membership in Ukraine and the problem of territorial integrity in Georgia are key parts of the problem, along with unstable political situations in both countries and low levels of success in achieving security sector reforms. One could say that those are not insurmountable obstacles in light of the fact that decisions about NATO's membership are predominantly political in nature, with or without MAP. But the situation is not so simple, even if we assume that NATO will eventually issue an invitation to both states. From this perspective, it is not likely that Ukraine would be capable of conducting a referendum on the issue of NATO accession that would result in a positive decision. It is even less likely that South Ossetia and Abkhazia would voluntarily integrate into Georgia, or that Georgia would be ready to surrender those parts of its territory in favor of NATO membership.

Thus, the answers to the questions posed at the outset of this article are necessarily incomplete, although it is possible to draw some provisional conclusions:

1. Is the current debate about NATO enlargement to include Ukraine and Georgia similar to earlier enlargement debates? The answer is no. All three postCold War NATO enlargement rounds were based on different circumstances, but with the same strong commitment by the United States to keep the process on track. The allies had different levels of enthusiasm for further enlargement at different times, but never opposed it publicly. Russia kept mentioning that NATO enlargement should not cross the "red line" of its sphere of interest, without any clear explanation of where that red line was and what Russia was prepared to do to prevent it. The Alliance never made an advance prediction regarding the membership of any aspirant. The debates about membership for Ukraine and Georgia have only one point in common with the previous ones: the United States' willingness to get these two countries into the Alliance. Some European allies, led by Germany and France, have publicly opposed their accession. Russia finally drew its vaunted "red line" with its military intervention in Georgia and with its highly public warning given to Ukraine. Nevertheless, the Alliance has committed itself to the future membership of Ukraine and Georgia.

2. Does geopolitics still matter in the eastward expansion of the Alliance? The answer to this question is yes. Geopolitics is important when assessing the enlargement process, both for those who pursue it and those who oppose it. With respect to the most important security issues of today-the fight against terrorism, the prevention of the proliferation of WMD, and concerns with energy security - the strategic positions of Ukraine and Georgia may make geopolitics more salient than ever. 
3. Why are Ukraine and Georgia part of the same NATO "enlargement package"? This essay has offered a comparative analysis of the differences and similarities regarding the two countries' aspirations to join NATO. Ukraine and Georgia are in the same "package" because they are the only two countries in the post-Soviet space that are not yet NATO members whose political elites have actively sought membership in the Alliance.

4. Does the debate over NATO enlargement to Ukraine and Georgia serve as a turning point in the future engagement between Russia and the West, and thereby in Russia-NATO relations? The answer to this question is complex, and has many aspects. I would argue that it does represent a turning point, and that now both sides must try to arrive at solutions that will enable the "fresh start" that U.S. Secretary of State Hillary Clinton called for. But this "fresh start" demands a change in the Cold War mindset on both sides. The new framework of transatlantic strategic thinking is still in the process of taking shape, and the cases of Georgia and Ukraine will be considered within it.

Ultimately, it is difficult to say more about future of NATO enlargement without a crystal ball. If we take the process of NATO enlargement as "old wine," we might say that the case of Ukraine and Georgia represents a new bottle for old wine. The problem with this bottle - and with the highly fraught prospect of NATO enlargement to Ukraine and Georgia - is that it is extremely fragile. 


\section{Bibliography}

Antonenko, Oksana. "A War with No Winners." Survival 50, no. 5 (2008): 23-36.

Baranovsky, Vladimir, and Alexei Arbatov. "The Changing Security Perspective in Europe." In Russia and the West: The 21st Century Security Environment, 59. New York: East West Institute, 1999.

Betts, Richard K.. "The Three Faces of NATO." The National Interest Online (2009).

Bucharest Summit Declaration, Issued by the Heads of State and Government participating in the meeting of the North Atlantic Council in Bucharest on 3 April 2008 In NATO Press Release. Bucharest, 2008.

Cohen, Saul B.. Geopolitics of the World System. Lanham, MD: Rowman \& Littlefield, 2002.

Dubovyk, Volodymyr. U.S.-Ukraine Relations, The Long Road to Strategic Partnership In PONARS Policy Memo. Washington, D.C.: Center for Strategic and International Studies, 2006.

Dunay, Pàl. "From Obsession to Oblivion: Reconceptualization of Security in NATO since 1990." In Globalization and Environmental Challenges: Reconceptualizing Security in the 21st Century, 718. New York: Springer, 2007.

Final communiqué, Meeting of the North Atlantic Council at the level of foreign ministers held at NATO Headquarters In Press Release. Brussels: NATO, 2008.

Final Communiqué, Meeting of the North Atlantic Council on the level of foreign ministers held at NATO Headquarters In Press Release. Brussels: NATO, 2008.

Finn, Peter. "Putin Threatens Ukraine On NATO." Washington Post (2008).

Fried, Daniel. "NATO: Enlargement and Effectiveness." Brookings.edu (2008).

Friedman, George. "Georgia and the Balance of Power." The New York Review of Books 55, no. 14 (2008): 25.

Geopolitical Diary: The Medvedev Doctrine. Stratfor (2008).

Georgia Lags in Its Bid to Fix Army. New York Times (2008).

Georgia: After Crackdown on Protests, President Calls Early Polls. Radio Free Europe/Radio Liberty, 2007.

Georgian Opposition Leader Launches New Party. VOANews.com, 2008.

Goldgeier, James M.. Not Whether but When. Washington, D.C.: Brookings Institution Press, 1999.

Hillary Clinton: NATO Must Make Fresh Start with Russia. Reuters, 2009.

Hillen, John, and Michael P. Noonan. "The Geopolitics of NATO Enlargement." Parameters 28, no. 3 (1998): 24. 
House, White. Fact Sheet: U.S. Support for Georgia; The United States Supports the Recovery, Stability, and Continued Growth of Georgia's Economy In Press Release. Washington, D.C., 2008.

Klare, Michael. Russia and Georgia: All About Oil. Foreign Policy in Focus, 2008.

Konieczna, Joanna. Ukraine after the "Orange Revolution": Changes in the Social Attitudes and Values In CES Report. Warsaw: The Centre for Eastern Studies, 2006.

Kuzio, Taras. "The Domestic Sources of Ukrainian Security Policy." The Journal of Strategic Studies 21, no. 4 (1998): 23.

Kuzio, Taras. "U.S.-Ukrainian Relations Return to "Golden Era." Ukrainian Observer (2006).

Kuzio, Taras. "U.S.-Ukrainian Relations Will not Revive under Kuchma." Kyiv Post (2003).

Kuzio, Taras. Ukraine: NATO Relationship. Research Update for Oxford Analytica, 2000 .

Larrabee, Stephen. NATO Enlargement: Prague and Beyond. IISS/CEPS European Security Forum, 2001.

Larrabee, Stephen. NATO's Eastern Agenda in a New Strategic Era. Santa Monica, CA: RAND Corporation, 2003.

Lavrov, Sergei. "Containing Russia: Back to the Future?" Russia in Global Affairs (2007).

Lukin, Alexander. "From a Post-Soviet to a Russian Foreign Policy." Russia in Global Affairs (2008).

Lukyanov, Fyodor. "Two Crises on the Way to Reshaping the World." Russia in Global Affairs (2008).

Mackinder, Halford. Democratic Ideals and Reality. New York: Henry Holt and Co., 1919.

Malek, Martin. "NATO and the South Caucasus: Armenia, Azerbaijan, and Georgia on Different Tracks." Connections: The Quarterly Journal 7, no. 3 (2008): 30-51.

Mandelbaum, Michael. The Dawn of Peace in Europe. New York: The Twentieth Century Fund Press, 1996.

Mattox, Gale A., and Arthur R. Rachwald. "Introduction: European Security and the Enlargement of NATO." In Enlarging NATO: The National Debates, 6. Boulder, CO: Lynne Rienner Publishers, 2001.

Mite, Valentinas. Ukraine: Would Hike in Russian Gas Prices Prove a Blessing in Disguise?. Payvand's Iran News, 2005.

Muraviev, Alexey. "Georgia: The Broader Geostrategic Considerations." Defence and Foreign Affairs Strategic Policy 36 (2008): 11. 
NATO Enlargement: Albania, Croatia, and Possible Future Candidates In CRS Report for Congress. Washington D.C.: Congressional Research Service, 2008.

NATO Expansion: Cost Issue In CRS Report for Congress. Washington D.C.: Congressional Research Service, 1997.

NATO Secretary-General Jaap de Hoop Scheffer, speech at an event jointly organized by the Institute for National Security Studies and the Atlantic Forum of Israel, Tel Aviv., 2009.

Nicholl, Helen R., and Nicholas J. Spykman. The Geography of the Peace. New York.: Harcourt, Brace, and Co, 1944.

Rice, Condoleezza. Remarks at the Signing Ceremony for the United States-Ukraine Charter on Strategic Partnership and Security. U.S. Secretary of State, 2008.

Rivlin, Paul. "Russia's Invasion of Georgia: Strategic Implications." TelAvivNotes (2008).

Rodman, Peter W.. "Will NATO Survive?" National Review (1995).

Russia Has no Alternative to Sevastopol Base-Naval Expert. GlobalSecurity.org, 2009.

Saakashvili, Mikheil. "Georgia’s Role in International Security Policy." Hampton Roads International Security Quarterly (2006): 5.

Sloan, Stanley R.. NATO, the EU, and the Atlantic Community: The Transatlantic Bargain Reconsidered. Lanham, MD: Rowan \& Littlefield, 2003.

Socor, Vladimir. "NATO Debates on Georgia and Ukraine Add Clarity about Russia." Eurasia Daily Monitor 5, no. 64 (2008).

Solomon, Gerald B. H.. The NATO Enlargement Debate, 1990-1997: Blessings of Liberty. Washington, D.C.: Center for Strategic and International Studies, 1997.

Trenin, Dmitry. The End of Eurasia: Russia on the Border between Geopolitics and Globalization. Washington D.C.: Carnegie Endowment for International Peace, 2001.

Ukraine Comes to the Forefront; Russia's Western Neighbors. The Economist (2008).

Ukraine's NATO Accession: Politics as Usual. Central Europe Digest (2008).

United States-Georgia Charter on Strategic Partnership. U.S. Department of State, 2009.

US Offers Georgia Road Map for Deeper Ties. The Guardian (2009).

Walt, Stephen M.. "Why Alliances Endure or Collapse." Survival 39, no. 1 (1997): 157.

Zeihan, Peter. The Russian Gas Trap. Stratfor Global Intelligence, 2009. 